\title{
Toward an Effective Supervision of Partially Dollarized Banking Systems
}

Jorge Cayazzo, Antonio Garcia Pascual, Eva Gutierrez, and Socorro Heysen 



\title{
IMF Working Paper
}

Monetary and Financial Systems Department

\section{Toward an Effective Supervision of Partially Dollarized Banking Systems}

\author{
Prepared by Jorge Cayazzo, Antonio Garcia Pascual, Eva Gutierrez, and Socorro Heysen ${ }^{1}$ \\ Authorized for distribution by David D. Marston
}

January 2006

\begin{abstract}

\section{This Working Paper should not be reported as representing the views of the IMF.} The views expressed in this Working Paper are those of the author(s) and do not necessarily represent those of the IMF or IMF policy. Working Papers describe research in progress by the author(s) and are published to elicit comments and to further debate.
\end{abstract}

The paper presents a supervisory framework that addresses the vulnerabilities of partially dollarized banking systems. The tendency to underprice systemic liquidity risk and currencyinduced credit risk creates vulnerabilities that need supervisory responses. The framework seeks to induce agents to better internalize risks by implementing a risk based approach to supervision, following the risk management guidelines of the Basel Committee, and by establishing buffers to cover higher liquidity and solvency risks. The paper also shows that most dollarized countries have addressed their liquidity vulnerabilities, but few have addressed those arising from currency-induced credit risks.

JEL Classification Numbers: G28, F31

Keywords: Bank Supervision, Financial Stability, Risk Management, Dollarization

Author(s) E-Mail Address: jcayazzo@imf.org; agarciapascual@imf.org; sheysen@imf.org; egutierrez@imf.org;

\footnotetext{
${ }^{1}$ We are grateful to S. Ramirez, V. Etropolska, M. Kitonga, and M.C. St. Louis for their valuable assistance. We also wish to thank P. Hayward, A. Ize, D. Marston, and P. Turner, as well as the participants at the Central Reserve Bank of Peru-IMF joint conference and an IMF seminar for valuable comments and suggestions. We are especially indebted to the supervisory authorities from the 17 countries that responded to our lengthy questionnaire and provided comments on an earlier version of this paper.
} 


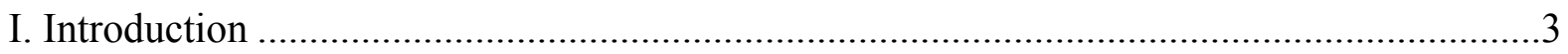

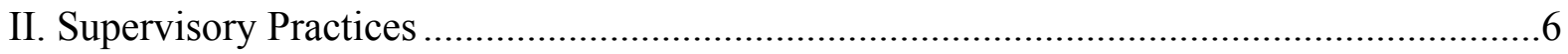

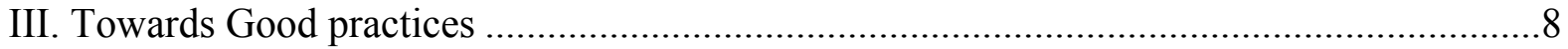

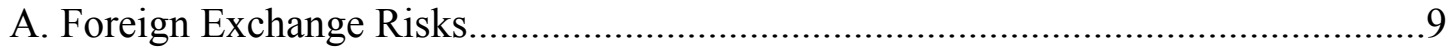

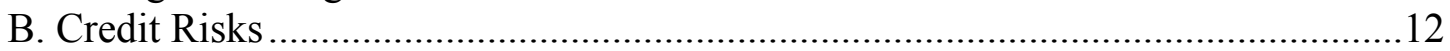

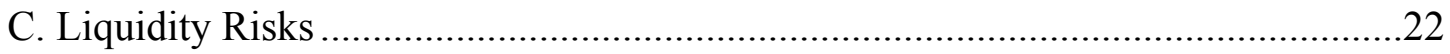

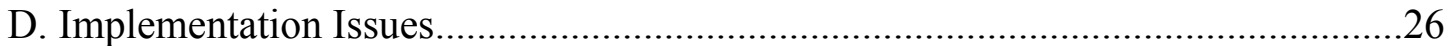

\section{Boxes}

1. How Does a Devaluation Affect the Capital Adequacy Ratio (CAR) of a Bank, Depending on its Foreign Exchange Position and Asset Dollarization? ....................11

2. Quantitative Assessment of Currency-Induced Credit Risk and its Application for Off-Site Supervision: The Case of Peru..................................................................21

3. Costs and Benefits of Prudential Requirements to Control Liquidity Risk: The Case of Peru

Appendices

I. Country Practices: Survey Results. .30

II. Currency-Induced Credit Risk in Selected Banking Systems 


\section{INTRODUCTION}

The Basel Committee for Banking Supervision (BCBS), through its 1998 Capital Accord and guidance material on risk management, established a comprehensive framework for the oversight of banking activities. This framework was revised in the context of Basel II (the revised international capital framework issued in 2004 and updated in 2005; see Basel Committee, 2005). The revised accord aligns the capital measurement with sound and contemporary practices in banking and promotes further improvements in risk management. The specific documents on the management and supervision of the main banking risks, including credit market and liquidity risks, in principle are applicable to all banking systems.

The purpose of this paper is to contribute to the design of a prudential regulatory framework for banks operating in partially dollarized economies, with the discussion being anchored conceptually in the framework of the comprehensive BCBS guidance on risk management. This paper does not address issues related to the causes of or solutions to dollarization. Causes are invariably related to macroeconomic and institutional factors, ${ }^{2}$ and accordingly, solutions are likely to focus on macroeconomic and institutional policies instead of microeconomic prudential regulations. Instead, the paper addresses the fact that financial systems and banks in most dollarized countries face higher risks that are reinforced by moral hazard. The resulting exposures create systemic vulnerabilities to which, from the standpoint of financial stability, supervisory regimes need to adapt. ${ }^{3}$

Partial dollarization increases the vulnerability of financial systems to solvency and liquidity risks $^{4}$. Increased solvency risks result mainly from foreign currency mismatches in the event of large movements of the exchange rate. In these countries, banks often provide foreign currency loans to unhedged borrowers expecting that the government will be willing and able to absorb exchange rate volatility. Banks' currency mismatches expose them to foreign exchange risk, while their borrowers currency mismatches expose them to foreign currencyinduced credit risk. Liquidity risk constitutes an additional source of risk, that stems from the potentially limited backing of banks' dollar liabilities and is often associated by (or triggered by) solvency risk.

Following international standards, partially dollarized countries control banks' foreign exchange risks by imposing limits or minimum capital requirements on foreign exchange exposures. While international standards provide an adequate framework for countries with significant exposure to foreign currency, one particular aspect that deserves special

\footnotetext{
${ }^{2}$ See Reinhart, Rogoff, and Savastano (2003).

${ }^{3}$ See Ize and Powell (2004), for a presentation of the need for prudential measures to reduce the vulnerabilities from dollarization.

${ }^{4}$ These vulnerabilities have been extensively discussed in Gulde et al. (2004) and De Nicoló, Honohan, and Ize (2003).
} 
consideration in countries with a high level of dollarization is the definition of a riskless position in foreign currency that is used when establishing prudential rules to control corresponding risks (capital charges and limits). This paper shows that a matched foreign exchange position is not riskless in a highly dollarized country because in the event of a depreciation, the capital adequacy ratio tends to fall more, the higher the rate of dollarization.

Banks' actions to contain the foreign exchange risk arising from intermediating dollar liabilities, often lead them to take higher credit risks. To reduce their foreign currency mismatches, banks acquire dollar denominated assets through granting foreign currency loans to domestic clients whose cash flow is in domestic currency. While effectively transferring the foreign exchange risk to the borrowers, banks retain the credit risk resulting from the possibility that the borrowers' currency mismatches affect their capacity to repay the loan in the face of adverse exchange rate fluctuations. Exposure to credit risk also increases if the value of the collateral backing the loan obligation-denominated in domestic currency - declines consequent on the exchange rate movement.

Implicit or explicit government guarantees distort pricing decisions and increase the demand and supply of foreign-exchange-denominated transactions. Borrowers, operating in the context of fixed exchange rate or "fear of floating" regimes, expect that the exchange rate risk will not materialize within the maturity of their loans in the face of prevalent short-term lending and spreads that are generally lower for intermediation in foreign currency relative to domestic currency. As a consequence, borrowers perceive that costs entailed in holding a currency mismatch in their balance sheets are lower in "normal" times than intermediating in a weak domestic currency where spreads and volatility tend to be higher. In some cases government guarantees further encourage foreign currency lending and borrowing. ${ }^{6}$ The limited availability of hedging instruments in many emerging markets and the shallowness of domestic credit markets may also provide a rationale for unhedged foreign currency lending. The facts are that the risk of large unexpected exchange rate movements is not priced in, large amounts of unhedged foreign currency loans are granted and banks tend to hold insufficient reserves - in the form of provisions or capital - to protect them. This is a problem that bank supervisors need to address.

Limited backing of banks' foreign currency liabilities by foreign currency and their convertibility at par create systemic liquidity risks. Systemic liquidity problems in dollarized economies arise when the demand for local assets falls, due to a perceived increase in country risk or banking risk, prompting depositors to convert their deposits into foreign currency, cash or to transfer them abroad and/or foreign banks to recall short-term lines of

\footnotetext{
${ }^{5}$ See Calvo and Reinhart (2002).

${ }^{6}$ Tornell and Westermann (2002) note that the incentive structure is sufficiently strong that small firms belonging to the non-tradable sector borrow more intensively in foreign exchange in periods of boom encouraged by bailout guarantees and sometimes real exchange rate appreciation. This explains the increase of the non tradable to tradable output ratio in these periods.
} 
credit. Unless there are sufficient liquid foreign currency assets to back liquid foreign currency liabilities, banks may run out of foreign currency liquid reserves and be unable to pay off foreign currency deposits. Similarly, central banks may run out of international reserves to provide foreign currency lender of last resort support to distressed banks. When this happens, deposit (or loan) contracts may need to be broken and disruptive or confiscatory measures taken, thereby validating creditors' fears and justifying the run. These systemic risks are often overlooked by banks, which prefer that the cost of holding additional liquid assets be borne by central banks. The regulatory framework governing liquidity in a dollarized economy should take into account that, regardless of the currency of deposits, liquidity risk is twofold: (i) individual bank risk due to isolated deposit withdrawals; and (ii) systemic risk in case of widespread deposit withdrawals.

In sum, one consequence of these moral hazards and institutional factors is that both, currency-induced credit risks and liquidity risks are underpriced and insufficiently hedged, including through adequate buffers to shocks. The combination of under pricing of risks and insufficient buffers can have serious consequences in the event of large unexpected shocks, not only for individual banks but for the financial system as a whole. In the context of the supervisory principle that the primary responsibility for bank solvency and liquidity rests on its shareholders and management, the prudential objective has to be to ensure that these risks are internalized appropriately. To this end, it is key that countries fully implement the Basel guidelines on the management of risks, paying special attention to the specific vulnerabilities that arise in a dollarized environment. However, qualitative guidance encouraging banks to adequately manage risks, while necessary, is unlikely to be sufficient in many partially dollarized emerging countries. Supervisors need to take an activist role to ensure that banks have adequate buffers to cover their risks, in the event of exceptional shocks. Prudential measures are needed in the form of higher capital or provisioning requirements to cover solvency risks arising from borrowers' currency mismatches and higher liquid assets to cover liquidity risks.

The paper is organized as follows. Section II provides evidence of current supervisory practices, showing that several partially dollarized countries have adopted measures to reduce vulnerabilities from foreign exchange and liquidity risks, but few have addressed those arising from currency-induced credit risks. Shortcomings in addressing vulnerabilities arise from both, the lack of full implementation of the Basel guidelines on risk management as well as the absence of necessary buffers to cover the solvency and liquidity risks taken by banks. Section III presents a framework to reduce the vulnerabilities of partially dollarized economies and discusses issues associated with its implementation. The framework suggests how Basel guidelines on risk management should be read to ensure that the vulnerabilities of highly dollarized financial systems are addressed and recommends the application of additional buffers to cover risks. Two appendices review current practices and country risk levels, respectively. 


\section{Supervisory Practices}

Current practices in most partially dollarized countries are not effectively addressing the vulnerabilities of dollarized environments. This shortcoming stems from two sources. First, many highly dollarized countries fall short of fully implementing the BCBS guidelines for the management of key risks. ${ }^{7}$ Second, few supervisors have taken provisions to ensure that the adequate buffers are in place to cover the higher solvency risks of these banking systems. Many countries have implemented measures to achieve adequate protection from foreign exchange and liquidity risks, but few have sought to ensure adequate protection to cover currency-induced credit risks. These observations are based on the results of a survey conducted between June and September 2004, in 17 countries in different parts of the world and at different levels of dollarization. The details are presented in Appendix I. ${ }^{8}$

All surveyed countries have implemented prudential regulations based on current international standards for controlling foreign exchange risks. Regulations include limits on or capital requirements for foreign exchange exposure. Many countries have switched from having limits on foreign exchange open positions to requiring capital for these positions and several have adopted both. In some cases, these regulations entail a structural open position (Lebanon) or asymmetric limits on open positions that allow relatively large long open positions (Bolivia and Peru). As is shown in the next section, in highly dollarized countries, asymmetric limits and structural open positions are generally better than symmetric ones in safeguarding banks' capital adequacy ratios in the event of a currency depreciation, but to fully protect banks' solvency, regulators would gain from redefining what constitutes a riskless foreign exchange position.

Most countries have implemented prudential measures to reduce the vulnerabilities of financial systems to liquidity risks. Following BCBS guidelines for the management of liquidity risks, they require banks to manage these risks, to conduct stress tests on a variety of scenarios and to implement contingency plans to address liquidity problems. These scenarios are generally based on the estimation of maturity gaps, which are in many cases currency specific. A handful of countries have introduced limits on maturity mismatches. Many highly dollarized countries utilize, additionally, a combination of prudential measures, mostly minimum liquidity ratios and reserve requirements to ensure that banks, and the banking system as a whole, have an adequate buffer of liquid assets to face stressful conditions. ${ }^{9}$

\footnotetext{
${ }^{7}$ Current standards are contained in various BCBS documents (see BCBS, 1997, 1999, 2000).

${ }^{8}$. The survey included six countries with more than half of total deposits in foreign currency (Bolivia, Croatia, Lebanon, Peru, Singapore and Uruguay), six countries with dollarization levels between 30 and 50 percent (Costa Rica, Honduras, Latvia, Romania, Slovenia and Turkey) and five countries with low levels of dollarization (Argentina, Brazil, Chile, Poland, and Sweden).

${ }^{9}$ Reserve requirements have been traditionally regarded as a monetary policy instrument to assist authorities in controlling the money supply, as the range of liquid assets (cash and central bank deposits) accepted to comply
}

(continued) 
These minimum requirements tend to be relatively high, with rates ranging from 10 to 40 percent, and may include high marginal rates for some liability types. Many countries also apply higher requirements for foreign currency relative to domestic currency liabilities, including some countries that apply liquidity requirements only for foreign currency liabilities (Croatia, Honduras, and Slovenia).

In contrast, the extent to which the countries' prudential regulatory framework deals with currency-induced risk is limited and very recent. Two-thirds of the surveyed countries with moderate to high dollarization have neither required banks to manage their currency-induced credit risks nor conducted stress tests that allow them to identify the relevance of this risk for their supervised banks. The remaining third of these countries, plus two former highly dollarized countries (Argentina and Poland), have generally focused their efforts towards requiring banks to manage their currency-induced credit risks and ensuring that they are measured through stress testing. Few have achieved progress to ensure that these risks are adequately priced and covered with a sufficient buffer. Only one of the responding countries (Uruguay) has recently required higher capital for foreign currency assets. ${ }^{10}$ Only one country (Peru) reports requiring higher provisions for foreign currency loans relative to domestic currency ones. Besides Peru, five other countries (Singapore, Poland, Lebanon, Argentina, and Chile) report that banks are expected to assign a higher risk rating to debtors whose capacity to repay is sensitive to exchange rate movements, in the context of their overall risk assessment of borrowers. It is interesting to note, however, that several highly dollarized countries have recognized that the 8 percent minimum capital standard does not provide sufficient cover from the credit risks they face and have implemented higher requirements. The most notable cases are Lebanon and Romania, which require a 12 percent minimum capital adequacy ratio.

It is not a coincidence that some countries with low dollarization levels (Argentina, Brazil, Chile) have taken administrative measures to control credit risks stemming from the use of foreign currencies, whereas highly dollarized countries have avoided them. The effectiveness of limits or prohibitions to grant foreign currency credit to unhedged borrowers is likely to be lower and the costs higher in countries that are already dollarized. The risk that these measures may cause disintermediation and that banks seek to exploit regulatory arbitrage to elude them would be higher once the dollar has been well established as an alternative currency in the financial system. Moreover, it is generally easier to take preventive action when dollarization is low than when it is already high. There is no easy solution for supervisors of highly dollarized countries, particularly with regards to controlling currencyinduced credit risks. However, it is encouraging that some of them are taking steps in the

with this minimum ratio are also central bank liabilities (base money). However, they have also been seen as a special type of liquidity ratio and as such they have been used as a prudential tool, operating as a buffer stock to face liquidity shocks.

${ }^{10}$ In August 2005, Uruguay approved higher capital requirements for foreign currency loans by establishing a 125 percent weight on these assets. This norm is scheduled to become effective in July 2006. 
right direction by devising plans to adapt their regulatory frameworks with a view to better internalizing risks stemming from partial dollarization and taking measures to insure against these risks.

\section{TOWARDS GOOD PRACTICES}

The tendency to underprice risks that make most partially dollarized banking systems more vulnerable warrants a proactive approach to prudential regulation and supervision. This proactive approach has to consider two key elements:

- The first element entails the implementation of risk-based supervision, along the lines of the Basel Core Principles for Effective Supervision (BCBS, 1997) and the guidelines for the management of credit, liquidity, and market risks, and taking into account their implications for highly dollarized financial systems. The guiding principle behind this is that the responsibility for managing risks lies in banking institutions. However, supervisors can use their powers to induce banks to better manage their risks by setting high standards for risk management. In a dollarized environment, this implies that the supervisory processes should seek to ensure that banks adequately manage all their risks, including currency-induced credit risk and liquidity risks of a systemic origin. These aspects are frequently overlooked by supervisors of highly dollarized countries.

- The second element requires that supervisors ensure that banks have adequate buffers to protect their solvency and liquidity from these risks, including a reasonable protection for large low-probability shocks. These large shocks would be left largely uncovered if unregulated and could have serious consequences, not only for individual banks, but for the banking system as a whole and, thus, for financial stability. Reasonable buffers should be calculated based on an assessment of the shocks that could occur and their potential impact on bank solvency and liquidity. The main goals would be to compensate for the underlying distortions that lead to the underpricing of risks, as close as possible to their source and to induce agents to better internalize and price the risks of operating in a dollarized environment. Minimum capital and provisioning requirements should be used to create the reasonable buffer to protect banks solvency from all credit risks, including currencyinduced credit risks. In turn, minimum liquidity standards are recommended to create a buffer for liquidity risks.

The framework presented below is consistent with international standards, but the discussion goes into details not covered in these standards. In some instances, full implementation of current international standards, as reflected in Basel I, would not suffice to adequately address the vulnerabilities of a dollarized banking system. These cases are associated with the combination of policies to achieve the necessary buffers to cover risks from dollarization and are explicitly acknowledged and discussed. Some countries may face restrictions that prevent them from addressing their vulnerabilities while at the same time adhering to international standards. These cases are also discussed. The rest of the section presents the 
proposed measures to address foreign exchange, credit, and liquidity risks in dollarized financial systems and issues associated with their implementation.

\section{A. Foreign Exchange Risks}

International standards to manage and control market risk provide an adequate framework for countries with significant exposure in foreign currency. These standards stress that banking supervisors must be satisfied that banks have in place systems that accurately measure and monitor and adequately control market risks. Supervisors should have powers to impose specific limits and /or a specific capital charge on market risk exposures, including on foreign exchange business, if warranted.

Determination of a "risk-free position" is necessary before deciding whether foreign exchange risks are to be priced and/or limited. Traditionally, a net currency position is measured as assets minus liabilities for each currency. A position in which assets and liabilities are matched in each currency (net open position $=0$ ) is considered to be a risk-free position. This traditional method assumes that a risky position occurs only when an exchange rate movement may result in accounting losses or gains, which would happen either in case of a long net position (foreign currency assets $>$ foreign currency liabilities) or a short net position (foreign currency assets $<$ foreign currency liabilities).

While a matched foreign open position will protect the level of a bank's capital, expressed in domestic currency, in the event of exchange rate movements, it does not always protect the capital adequacy ratio (CAR). In fact, in highly dollarized systems, exchange rate movements could have a significant impact on the CAR of banks with a perfectly matched foreign open position. As shown in Box 1, the larger the difference between the ratio of dollarization and the foreign exchange position as a percent of capital, the higher the impact of an exchange rate movement on the CAR. In the example, a 20 percent depreciation lowers the CAR from 10 percent to 8.8 percent for a bank with a 67 percent dollarization which keeps a matched foreign open position. In turn, if this bank kept a foreign open position equivalent to its rate of dollarization, it would maintain its CAR at the 10 percent initial level.

This problem is mitigated, but not fully resolved, by the structural position allowed by the Basel Committee (BCBS, 1998). According to the Basel Committee, banks may be allowed to protect their CAR by excluding from the calculation of their net open position, any position they have deliberately taken to hedge partially or totally against the adverse effect of the exchange rate. For this exclusion, three conditions have to be met: (i) the positions have to be of a non-dealing nature; (ii) the position does no more than protect the bank's adequacy ratio; and (iii) any exclusion needs to be applied consistently during the life of the asset. Thus, banks can choose a structural position, thereby determining the degree of protection of their CAR.

It would be desirable to have a prudential approach aiming to protect the CAR. To control foreign exchange risks, supervisors may wish to center the calculation of capital charges and/or limits on the actual level of dollarization of each bank. Under this approach, banks 
would be required to fully hedge their CAR ratio from exchange rate movements, and the structural position would not be a choice. For this approach to effectively hedge capital, gains in the open position should be tax exempt. As an example, should a bank have 30 percent of its assets in foreign currency, and supervisors establish a limit of 20 percent of risk-tolerance, the corresponding limit for this bank would be a band of 20 percent both below and above its current dollarization level, which results in an open position not below 10 percent of capital, nor above 50 percent of capital (see Box 1 for details). 
Box 1. How does a devaluation affect the capital adequacy ratio (CAR) of a bank, depending on its foreign exchange position and asset dollarization?

The example below is a simple way to illustrate that the capital adequacy ratio of a bank will fall/grow with a depreciation/appreciation of the local currency (LC), if its foreign exchange (FX) open position, as a proportion of capital, differs from the level of dollarization of its assets. Let's assume the following initial situation:

Bank A (matched foreign open position; 67 percent dollarization of assets)

$\begin{array}{lllllr}\text { FX assets } & = & 200 & \text { FX liabilities } & = & 200 \\ \text { LC assets } & = & 100 & \text { LC liabilities } & = & 70 \\ & & & \text { Capital } & = & 30\end{array}$

FX open position $=\quad 0(200-200)$

CAR $=\mathbf{1 0}$ percent (for simplicity, it is assumed the all assets weight 100 percent for capital adequacy purposes)

Bank B (mismatched, set at the level of dollarization of assets; 67 percent dollarization of assets)

$\begin{array}{lllllr}\mathrm{FX} \text { assets } & = & 200 & \text { FX liabilities } & = & 180 \\ \mathrm{LC} \text { assets } & = & 100 & \text { LC liabilities } & = & 90 \\ & & & \text { Capital } & = & 30\end{array}$

FX open position $=$

20, equivalent to 67 percent of capital

CAR $=10$ percent

What would happen after a 20 percent depreciation of the domestic currency?

Bank A (matched)

$\begin{array}{lllllr}\text { FX assets } & = & 240 & \text { FX liabilities } & = & 240 \\ \text { LC assets } & = & 100 & \text { LC liabilities } & = & 70 \\ & & & \text { Capital } & = & 30\end{array}$

CAR

8.8 percent

Bank B (mismatched)

$\begin{array}{lllllr}\text { FX assets } & = & 240 & \text { FX liabilities } & = & 216 \\ \text { LC assets } & = & 100 & \text { LC liabilities } & = & 90 \\ & & & \text { Capital } & = & 34\end{array}$

CAR $=10$ percent

As shown above, the presence of the high level of dollarization of total bank assets makes it necessary to carefully assess the convenience of having regulatory requirements in which limits or capital charges are based upon the belief that a matched net position is risk-free and a mismatched position is not. 


\section{B. Credit Risks}

Unexpected exchange rate movements generate currency-induced credit risks that, in partially dollarized banking systems, tend to be highly underpriced. Banks and borrowers, operating in fixed exchange rate or "fear of floating" regimes, expect that the exchange rate risk will not materialize within the maturity of their loans in the face of prevalent spreads that are generally lower for intermediation in foreign currency relative to domestic currency. As a consequence, borrowers perceive that costs entailed in holding a currency mismatch in their balance sheets are lower in "normal" times than intermediating in a weak domestic currency where spreads and volatility tend to be higher. However, when a large unexpected movement of the exchange rate does occur, these currency mismatches affect borrowers' capacity to repay and cause large losses for banking institutions. Because of these losses, central banks tend to avoid a sharp depreciation of the currency as long as they can. ${ }^{11}$ Thus, most of the time, banks' and borrowers' expectations are validated by the behavior of the central bank, and the currency-induced credit risk stays under priced, large amounts of unhedged foreign currency loans are granted and banks tend to hold insufficient reserves - in the form of provisions or capital - to protect them from this event. This section presents a prudential framework that addresses this problem.

An effective approach to the supervision of credit risks in a highly dollarized environment needs to consider two elements: (i) a supervision that pays attention to currency-induced credit risks; (ii) the constitution of a reasonable buffer to cover all credit risks, including those stemming from large unexpected shocks to the exchange rate. The first element should be based on a thorough implementation of the BCBS Principles for the Management of Credit Risk (BCBS, 1999), considering the implications of these principles in a dollarized environment. The second element should be based on an assessment of the shocks that could occur and their potential impact on banks' solvency. The main goal of this approach is to induce agents to better internalize and price the risks of operating in a dollarized environment. Minimum capital and provisioning requirements should be used to create the reasonable buffer to protect banks' solvency from all credit risks, including currency-induced credit risks. Generally, capital covers unexpected losses, while provisions are constituted to cover expected losses, either identified (covered by specific provisions) or latent losses not yet identified (covered by general provisions). Alternative options, to be considered when the preferred policy distribution is not be possible, are also discussed.

\section{Supervision of Credit Risks and Credit Risk Management}

International standards provide a solid basis for ensuring that financial institutions of dollarized economies manage their credit risks properly. The BCBS Principles for the Management of Credit Risk (BCBS, 1999) state that banks should operate under sound, well-

${ }^{11}$ See Calvo and Reinhart (2002). 
defined credit granting criteria, that should include a thorough understanding of the borrower, as well as the purpose and structure of the credit, and its source of repayment (Principle 4). Banks should also have information systems and analytical techniques which allow them to measure the credit risk inherent in all activities (Principle 11). Additionally, banks should consider the potential impact of future changes in economic conditions when assessing individual credits and credit portfolios, under normal and stressful conditions (Principle 13). Moreover, it is also explicitly noted that the contingent nature of market-sensitive-exposures, such as foreign exchange contracts, requires that banks have the ability to assess the probability distribution of the size of actual exposure in the future and its impact on both the borrower's and the bank's leverage and liquidity.

In countries with significant lending in foreign currencies, these principles imply that banks should pay particular attention to currency-induced credit risk. Issuing a regulation or guidelines on credit risk management that makes explicit reference to currency-induced credit risks could be of great assistance in ensuring that banks adequately manage these risks. This regulation should establish high minimum standards for credit risk management as well as responsibilities of directors and managers and disclosure requirements. Building up supervisory capacities to assess the adequacy of banks' credit risk management and exercising supervisory powers to ensure banks' compliance with these standards are essential. The main ingredients of the approach to the supervision of currency-induced credit risk are presented below.

Supervisors should ensure that banks gather enough information to measure the sensitivity of a borrower's capacity to repay under changing exchange rates. Banks could be required to gather information on borrowers' cash flows and balance sheets, distinguishing between domestic and foreign currencies for all relevant exposures. Even if a bank lends only in domestic currency, its borrowers' capacity to repay could be hampered in the event of a depreciation of the local currency if the borrower has significant liabilities in foreign currency with other counterparts. Also, credit bureaus could be encouraged to provide currency specific information on all debts, highlighting also (if relevant) debts indexed to the domestic price index or the exchange rate.

Separating assets and liabilities and revenues and expenditures by currencies is not a trivial exercise; it requires banks to have a deep knowledge of their customers and the markets where they operate. For instance, an importer who prices his products in dollars may still see his capacity to repay hindered by a depreciation if this causes a contraction in the demand for these products. An exporter who also sells in the domestic market could be negatively affected by a depreciation. In turn, a worker who earns domestic currency but receives remittances from abroad could maintain his capacity to repay in the event of a depreciation, particularly if the remittances come through the bank and are defined as the source of repayment.

While the exchange rate is expected to be the main source of indirect credit risk in dollarized financial systems, the significance of changes in interest rates should not be overlooked. Borrowers with domestic currency loans and floating interest rates or with a 
maturity mismatch could be an added source of credit risk, especially under fixed exchange rate or "fear of floating" regimes. ${ }^{12}$ In these cases, domestic currency interest rates tend to be more volatile, affecting the borrower's capacity to repay and the bank's exposure to credit risk.

Supervisors should make sure that banks' policies and procedures for the management of credit risks consider their exposure to currency-induced credit risks. Banks should define internal policies regarding their exposures to borrowers whose capacity to repay is sensitive to changes in the exchange rate and other market variables. These could include internal limits for these exposures and, in countries where these exposures are high, internal targets to reduce their risk from these exposures. The risk reduction could be achieved by reducing the exposure to these borrowers or by encouraging borrowers to reduce their currency mismatches. Offering hedging products or charging interest rates that better reflect the currency-induced credit risks could be used for this purpose. Banks should assess their loan pricing policies to ensure that they adequately reflect overall credit risk. Special attention could be given to setting policies regarding granting foreign currency loans to individuals (for consumer goods or housing).

Banks should be required to assess the sensitivity of their borrowers' capacity to repay in the event of changes in exchange rates, interest rates, and output and should base their credit decisions on such assessments. These assessments could be done individually for larger borrowers using information on currency specific cash flows and balance sheets to project their capacity to repay under changing conditions. For smaller borrowers which have homogeneous characteristics, such as individuals or small firms in a particular sector, the assessment could be done on a group basis. The information on currency specific cash flows and balance sheets may not be available for small businesses. Unless better information is available, it would be prudent to assume that all the income of these borrowers and of individuals is denominated in domestic currency.

The selection of scenarios and assumptions for the shocks to be tested are key to assessing the credit risk embedded in the bank portfolio. Supervisors could let banks define the scenarios and changes in the main market variables and assess them at the time of the supervisory review. Alternatively, supervisors could choose to provide assumptions for these changes (exchange rate, interest rate, output). This latter option has the advantage of making the results of the stress tests comparable and easier to review by supervisors. Admittedly, however, under certain circumstances, these assumptions could be interpreted as signals and produce undesirable responses.

Banks should be able to calculate the expected losses from their loan portfolios, including those that could arise from borrowers' currency, interest rate, or maturity mismatches. These will depend on the borrowers' probability of default, on the bank's exposure at the time of

${ }^{12}$ See Calvo and Reinhart (2002). 
default and on the bank's loss-given-default. While it may not be realistic to expect that all banks in all countries will have the capability to estimate default probabilities, the abovementioned assessment of capacity to repay should provide a basis for estimating expected losses. In turn, to estimate loss-given-default, banks should be able to assess the recovery value of collateral, which depends on the market value of collateral and on the costs of recovery (taking into account the time it takes to foreclose and fully recover the collateral).

As the recovery value of collateral can also be affected by market conditions, banks should assess this value for changing market conditions. Availability of information on most asset prices is a difficulty that would need to be overcome in most countries. When collateral is difficult to recover, highly illiquid, or its price cannot be estimated, it may be advisable to disregard such collateral. In other cases, frequent appraisals of relevant collateral are an option, albeit costly, for obtaining this information. Alternatively, previously appraised collateral values could be adjusted frequently, using simplified methods to be reviewed by supervisors. For instance, the foreign currency value of real estate collateral could be expected to fall in the event of a depreciation of the domestic currency. In the absence of better information, banks could assume that real estate prices are set in domestic currency, and thus their fall would be proportional to the depreciation of the currency. This method would probably provide a worst-case scenario.

Banks should be required to disclose to the public their policies on credit risk management, and their main exposures, including currency-induced credit risks. This disclosure should be required at least annually, as part of audited financial statements. The availability of this information to the public could foster market discipline as sophisticated creditors would penalize banks that take higher risks, increasing their costs of raising equity or funds, and thus, perhaps encouraging more prudent behavior. However, to prevent disclosure from causing a loss of confidence, disclosure requirements could be phased in so as to give time for improvements in risk management.

Supervisors should conduct independent assessments of banks' exposure to credit risks, including currency-induced credit risks. These assessments should be done for individual banks and for the overall banking system. Stress testing techniques could be used to estimate banks' exposure to credit risks under changing market conditions. These stress tests could be conducted with information regularly provided by banks and available in the supervisory data bases. Supervisors should have access to detailed information at the borrower level, of a credit bureau type, for the purpose of conducting these stress tests. Alternatively, supervisors should always have the option to define specific stress test scenarios, and require banks to run them. These off-site assessments should be complemented with an on-site evaluation of banks' main exposures to credit risks. Box 2 presents an example of simple stress tests that could be applied by supervisors. A more detailed presentation of these tests and the results is included in Appendix II.

While imposing direct limits or prohibitions on granting foreign currency loans to unhedged borrowers seems to have worked for some countries, such as Brazil or Chile, their application to highly dollarized financial systems may not be advisable. It is worth noting that these 
measures tend to be used by countries where high dollarization has not yet become a problem. Their applicability in countries that are already highly dollarized is likely to be limited. Administrative measures tend to introduce distortions and have high costs of their own, particularly in countries where the use of the dollar in the financial system is well engrained. On efficiency grounds it seems preferable to let banks manage their own risks. Besides, these measures tend to create the largest incentives to seek mechanisms to avoid them, such as regulatory arbitrage. Their application should be carefully evaluated to avoid incurring high costs.

\section{Loan classification and provisioning for expected losses}

Banks should be required to have loan classification systems that reflect the borrowers' capacity to repay and to take into account sensitivity to expected changes in market conditions (e.g., exchange rate, interest rates, output). Loan classification rules in some partially dollarized emerging countries are still based on past payments performance. These need to be phased out and replaced by more forward-looking rules. In particular, a borrower should be downgraded, even if he has always been current on all payments, if his projected cash flow is not adequate to fully service all his debts under expected market conditions. The degree of downgrading should also be related to the extent of the impairment of the borrower's repayment capacity under likely scenarios. Note that this approach does not imply that foreign currency borrowers who do not have a foreign currency income should be automatically downgraded.

Loan loss provisions should reflect the above-mentioned impairment of borrowers' capacity to repay arising from expected changes in market conditions. This requirement would tend to produce higher provisioning requirements for foreign currency borrowers whose cash flow is negatively affected by a depreciation of the domestic currency. In this regard, it would also induce banks to better internalize the risks of lending in foreign currency to unhedged borrowers. A combination of specific and general provisions could be applied for this purpose. Specific provisions could be applied when expected losses are estimated for individual borrowers, and general provisions when the estimation of expected losses results from aggregate tests.

The application of loan classification and provisioning rules, based on the capacity to repay and expected losses, requires banks and supervisors to have analytical capabilities that may not currently be in place in some countries. As developing these capabilities takes time, in the meantime, two simplified options could be explored:

- $\quad$ The first one is a prescriptive approach, whereby the loan classification and provisioning regulation could establish automatic downgrades (and higher provisions) for particular borrower types, whose capacity to repay is perceived to be highly sensitive to expected changes in the exchange rate. These rules would have to be designed for each particular country, taking into account its specific market conditions and institutions. For instance, if individuals are significantly leveraged with foreign currency liabilities, a small depreciation of the currency could have a 
large impact on their repayment capacity and, hence, authorities could single out foreign currency loans to individuals and require a higher provision. In other countries, corporates that borrow in dollars and specialize in the nontradable sector could be perceived as a problem, and additional provisions could be prescribed for these borrowers, except those for whom banks can show that their capacity to repay would withstand some threshold shock regarding the exchange rate. While simple to implement, this prescriptive approach has a number of drawbacks, as it creates arbitrary divisions between types of borrowers, may create incentives to try to avoid the added costs and, if badly designed, may not help to better internalize risks.

- $\quad$ The second one requires banks to develop the above-mentioned systems and capabilities to classify and determine provisions for debtors on the basis of expected losses. Those banks that, in the view of the supervisory authority, do not have appropriate systems in place, would be required to have an additional general provision on their overall foreign currency portfolio. Provided that this provision is set at a high enough level, this approach has the advantages of creating the right incentive for banks to develop their systems and capabilities to assess their credit risks, and of providing a buffer that could cover potential shocks. The size of this provision would have to be carefully set to be higher than (or similar to) estimated specific provisions under an expected loss provisioning system.

\section{A buffer to cover unexpected losses}

Supervisors of highly dollarized banking systems also need to make sure that banks hold enough capital to cover from credit risk caused by unexpected changes in the exchange rate. Authorities must decide the size of the buffer that would provide this protection, and the policy combination to achieve it. The buffer should: (i) provide reasonable cover for large, low-probability shocks to the exchange rate; and (ii) be risk-sensitive to induce agents to better internalize currency-induced credit risks. Preferably, the added requirement should apply only to assets originating currency-induced credit risks, i.e., operations with debtors whose capacity to repay is hampered with a depreciation (unhedged borrowers). Under international standards, capital would be required to cover unexpected losses, and provisions would only be required to cover expected losses. However, for reasons to be discussed below, some authorities may choose provisions instead of capital to create a buffer to cover the above-mentioned unexpected losses. For simplicity, the decision about the size of the buffer is presented independently of the one about the policy choices.

\section{The size of the buffer}

The size of the regulatory buffer to cover currency-induced credit risks would depend on: (i) the impact of the exchange rate shocks on the value of banks' portfolios, (ii) the probability distribution of exchange rate shocks, and (iii) the degree of protection authorities are comfortable with. Since the shocks and their impact on the value of portfolios are subject to a large degree of uncertainty, the decision will be affected by the availability of information and by assumptions made. In turn, the degree of protection sought by policymakers should 
take into account that higher protection increases the cost of conducting banking business. These three elements are discussed:

- Impact of exchange rate shocks on the value of banks' portfolios. The quantitative assessment of currency-induced credit risk typically involves (i) econometric estimation of the relationship between exchange rate movements and a measure of credit risk, using either aggregate bank data or the financial information of the borrowers, or (ii) forward-looking assessment of the impact of a devaluation on the repayment capacity of the borrower measured by its interest coverage ratio or other financial indicator. The first methodology relies on past information that may not provide a good indicator of the effect of a future depreciation in the event of changes in regulation or changes in the underlying quality of borrowers. The second methodology requires information on the currency composition of the borrowers' balance sheet and income statement that might not always be available. Both methods rely on the quality of information available and the adequacy of the period of time covered by such information. For instance, currency-induced credit risk could be underestimated if the data available corresponds to a period of economic prosperity (i.e., the upturn of an economic cycle). An example of an assessment of this risk, under the first method, is presented in Box 2, where it is used to examine the size of the buffer needed to cover currency-induced credit risk of various depreciation levels (details are presented in Appendix II).

- $\quad$ Probability distribution of exchange rate shocks. ${ }^{13}$ To estimate the probability distribution of exchange rate movements, authorities may refer to past information on exchange rates in the local economy. This approach has the drawback that past information regarding exchange rate changes may not be a good predictor of future changes, particularly for countries with fixed or managed exchange rates, where imbalances have only recently arisen. ${ }^{14}$ An alternative option could be using historical information from similar countries that have experienced exchange rate shocks or simulations using a macroeconomic model that captures the accumulating imbalances or the distribution of exchange rate changes in a country with similar characteristics. Care must be taken by supervisory authorities to prevent simulations of exchange rate shocks being regarded as a signal of a change in the exchange rate regime or a

\footnotetext{
${ }^{13}$ Banks' exposure to credit risk may be simultaneously affected by several market variables, including the exchange rate, interest rates, inflation, and the level of economic activity. Authorities may consider these shocks individually or jointly, taking into account the correlations between these variables. While acknowledging this, the focus is put on exchange rate shocks.

${ }^{14}$ A long enough history that includes the events leading to dollarization is likely to also contain large exchange rate variations. However, these events might be hard to replicate under the improved monetary management applied in most highly dollarized countries in the recent past.
} 
decision to pursue policies inconsistent with maintaining this regime. ${ }^{15}$ In all cases the resulting probability distribution would also be affected by the selection of the sample period.

- $\quad$ The desired level of protection from currency-induced credit risk. Authorities would have to decide their risk tolerance level for currency-induced credit risk. In particular, from what level of depreciation should banks be protected (covered)? Should they be protected from 99 percent of possible levels of depreciation or only from 95 percent of them? The larger the depreciation they want protection from, the larger the buffer that banks would have to hold and, thus, the higher the cost of doing banking business. Therefore, authorities should gauge the benefits from additional protection - measured as the reduction of risks from depreciation - against the additional costs of conducting banking business. The additional costs of conducting banking business ( $\mathrm{Ci}$ ) caused when protecting against an "i" percent devaluation can be measured as the product of the size of the buffer $(\mathrm{Bi})$ required to protect against an "i" percent devaluation times the opportunity cost of capital $(r)$ in percent of output (GDP) or bank profits (P) ${ }^{16}$

$$
\mathrm{Ci}=\mathrm{r} * \mathrm{Bi} / \mathrm{GDP} \quad \text { or } \quad \mathrm{Ci}=\mathrm{r} * \mathrm{Bi} / \mathrm{P} \text {. }
$$

\section{The policy choice: capital versus provisions}

The decision on the policy choice to achieve the buffer is not an easy one. Increasing capital to cover unexpected losses may not be feasible in many emerging countries. First, in a Basle I framework, capital requirements are rather inflexible and provisions allow for a better targeted approach - more sensitive to risks - and thus could produce better results in terms of internalizing currency-induced credit risks. ${ }^{17}$ Second, in most emerging countries, a capital increase would demand a change in legislation, and thus would require more time and coordination. For these reasons, some authorities may prefer to require higher provisions instead of higher capital.

\footnotetext{
${ }^{15}$ An additional complication occurs when authorities are committed not to devalue, as is the case in currency board regimes. From a prudential point of view, authorities may still want to built up a buffer to cover from this unlikely event. The way this buffer is communicated is particularly important in this case, so as not to create mixed signals or self-fulfilling prophecies.

${ }^{16}$ Other potential costs may arise as banks seek to elude the added cost of doing banking business. These include the possibility of disintermediation and regulatory arbitrage, which are more difficult to assess.

${ }^{17}$ Basel II capital standards would captured these effects, under the Internal Ratings-Based (IRB) approach. However, Basel II is to be available for implementation in G-10 countries only in early 2007, and many highly dollarized countries may choose not implement it until much later, not to implement the more sophisticated IRB approaches, or not to implement the Pillar I of Basel II.
} 
When capital is the policy choice, the challenge for authorities is to make these requirements as risk-sensitive as possible in a Basel I framework. An increase in capital requirements across the board will not do this job. The same objection applies to an increase in capital or provisioning requirements for all foreign currency assets. The use of higher risk weights for assets that are sensitive to currency-induced credit risk would be the best way to do that.

When provisions are the policy choice, the added requirement can be incorporated into the loan classification and provisioning approaches presented above. Adding the buffer requires the use of the particular depreciation that corresponds to the desired level of protection for the analysis of the sensitivity of borrowers' capacity to repay. Under this option, there is no need to distinguish between expected and unexpected exchange rate movements. Specific provisions could be required when the sensitivity analysis is conducted individually, and general provisions could be required when borrowers are assessed as a pool.

The use of provisions to cover losses in the event of unexpected exchange rate movements departs from International Financial Reporting Standards (IFRS), shortly to be adopted by many developed and emerging countries. In fact, under International Accounting Standard (IAS) 39, assets should be subject to specific provisions when they are impaired, i.e., when there is a known event causing the impairment of the loan. Strictly speaking, a future unexpected depreciation does not qualify as a "known event".

General provisions, on the other hand, can be required for losses that can be estimated in a pool and have not yet been individualized. Thus, under IAS 39, banks would not hold specific or general provisions to cover for the sensitivity of a borrower's capacity to repay in the event of an unexpected depreciation. These potential losses would have to be covered by capital requirements. However, authorities that face difficulties in modifying capital requirements can choose to depart from IFRS on this particular subject, for prudential reasons. 


\section{Box 2. Quantitative Assessment of Currency-Induced Credit Risk: The Case of Peru}

The impact of exchange rate shocks on the foreign (FX) loan portfolio (see Appendix II for details). In the case of Peru, the econometric estimation of the relationship between provisions and depreciation show that a 1 percent depreciation results in a 1.9 percent increase in the growth of provisions on FX loans:

Growth(FX_loan_provisions/FX_loans) $=1.9 *$ Depreciation + f[GDP growth; Lending Rate; Inflation].

The probability distribution of exchange rate shocks and the desired level of protection against currency-induced credit risk. With these econometric estimates, a bank supervisor can assess the minimum capital buffer for a bank to withstand, for example, a $99^{\text {th }}$ percentile exchange-rate shock. The historical distribution of exchange-rate shocks in Peru since mid 1992 shows that the $99^{\text {th }}$ percentile corresponds to a depreciation of 43 percent. Clearly, the larger the shock the supervisor would like to protect against, the more costly in terms of bank capital. Consequently, the supervisor may consider capital buffers against more moderate shocks, such as a 20 percent depreciation $\left(90^{\text {th }}\right.$ percentile shock).

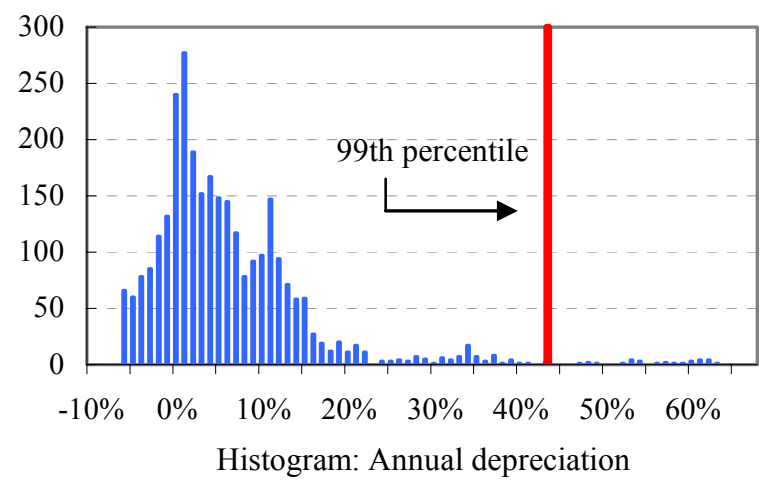

The capital buffer will depend on the size of the exposures, including the FX loan portfolio, and can be set in terms of additional provisions on FX loans or additional capital charges. The figure below shows (i) the capital buffer against an annual depreciation of " $x$ " percent and, as an alternative measure (ii) the risk weight on FX loans that would ensure compliance with the minimum regulatory CAR of 9.2 percent. The buffer has been calibrated to the level of RWA and FX loans of Peru's banking system. The calculation of the capital buffer assumes that the net FX open position in the banking system is similar to the degree of loan dollarization, however, if the degree of loan dollarization is above the net open position, a larger capital buffer would be needed (see Box 1 for details).

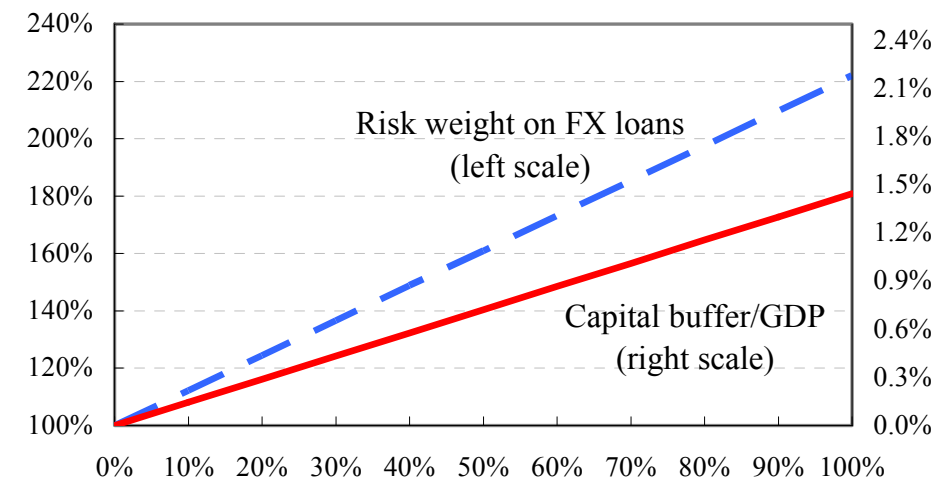

Annual depreciation 


\section{Liquidity Risks}

Liquidity risks are twofold: (i) idiosyncratic, affecting individual banks and generally related to their own behavior; and (ii) systemic, in case of widespread liquidity problems, generally stemming from macroeconomic fundamentals, contagion or generalized panic. While both risks are present in all financial systems, dollarized financial systems tend to be more vulnerable to systemic liquidity risks. Systemic liquidity problems arise when the demand for local assets falls, due to a perceived increase in country risk or banking risk, prompting depositors to convert their deposits into foreign currency or cash or to transfer them abroad, and/or foreign banks to recall short-term lines of credit. Unless there are sufficient liquid foreign currency assets to back liquid foreign currency liabilities, banks may run out of foreign currency liquid reserves and central banks may run out of international reserves, creating the conditions for a self-fulfilling run. Central banks can print domestic currency to provide lender of last resort (LOLR) facilities, however in foreign currency the LOLR capacity is limited by their holdings of international reserves. Ize, Kiguel and Levi Yeyati (2005) have shown that requiring banks to hold a minimum level of foreign currency liquidity in proportion to their foreign currency liabilities is a second best policy that would ensure that banks do not free ride on the central bank LOLR, transferring the cost of holding liquidity to the public sector and that weaker risk-prone banks do not benefit from the LOLR facilities at the expense of the more prudent banks.

Because of these added risks, the supervisory framework of a highly dollarized banking system should include two elements: (i) a risk based supervision of liquidity risks and their management; and (ii) some type of minimum liquidity requirement to ensure that banks internalize the liquidity risks of operating in a dollarized environment. The first element should be based on the BCBS guidelines on liquidity risk management, taking into account the higher relevance of currency specific and systemic liquidity risks. The second element could be designed as a minimum liquidity requirement or as a minimum reserve requirement. ${ }^{18}$ Since the goal is to induce banks to better internalize the costs of the liquidity risks, the level of these requirements has to be designed with this objective in mind. An alternative instrument, limits on maturity gaps, is effective for the management of idiosyncratic risks, but may not be as effective in ensuring adequate levels of foreign currency liquid assets in the event of systemic liquidity problems. These issues are discussed below.

\section{Supervision of liquidity risk and liquidity risk management}

The international standards on liquidity management, presented in Sound Practices for Managing Liquidity in Banking Organizations (BCBS, 2000) are a key reference for bank supervisors and are applicable to highly dollarized financial systems. These practices state

\footnotetext{
${ }^{18}$ In the first case, the liquid assets are managed by banks, whereas in the second case, these are managed by the central bank and are mostly constituted by central bank liabilities.
} 
that banks should have a strategy for the management of liquidity (Principle 1) with policies approved by the Board (Principle 2). Banks should also establish a process for the ongoing measurement and monitoring of net funding requirements, analyze liquidity under a variety of "what if" scenarios, review their assumptions frequently to ensure they continue to be valid and have contingency plans to handle liquidity crises (Principles 5, 6, 7 and 9). Moreover, currency-specific issues, which are a key concern in dollarized financial systems, are also explicitly addressed. Thus, banks are expected to have a system to measure, monitor and control their liquidity position in the major currencies in which they are active, and should undertake a separate analysis of their strategy for each currency individually (Principle 10). Based on this analysis, banks are expected to set and review internal limits on the size of their cash flow mismatches over particular time horizons for foreign currencies in aggregate and for each significant individual currency in which they operate (Principle 11).

Banks' processes for the ongoing determination and monitoring of net funding requirements should identify funding needs in the main currencies in which they conduct operations. This entails measuring all cash inflows against all cash outflows in each main currency, from all possible sources, including off-balance-sheet items. Immediate funding requirements, as well as future needs, should be determined. A variety of methods can be used for this purpose, but banks should consider not only contractual maturity but observed behavior. Careful profiling of behavior is essential for banks to adequately assess funding requirements under changing market conditions and make sound liquidity decisions. This approach should also be used to monitor compliance with internal limits as well as regulatory limits or cash requirements.

Liquidity analysis should consider a variety of stress tests of individual as well as systemwide disturbances, including the two main specific sources of liquidity risks for dollarized financial systems. First, scenarios should assess the impact on liquidity of changes in market conditions, such as a currency depreciation or rising interest rates, taking into account a bank's exposure to currency-induced and interest-rate-induced credit risk. These indirect credit risks will affect a bank's liquidity, as assets may not be repaid under their original terms and may also be difficult and costly to sell under stressful conditions. Moreover, the resulting solvency vulnerability increase the probability of a deposit run against all the banks that are perceived to share this problem, and may lead to systemic liquidity problems. Second, scenarios should model the impact on liquidity of currency specific asset and liability volatility experienced in the past or likely to occur, including possible cases of capital flight. The evolution of a bank's currency-specific and overall liquidity profile - as measured by a maturity ladder or by ratios of liquid assets - under a variety of scenarios can be a useful benchmark for assessing the bank's liquidity and for determining the action to be taken to improve the bank's performance under those conditions.

Banks' contingency plans should: (i) address their strategy for handling individual as well as system-wide liquidity crises; and (ii) establish procedures for making up cash-flow shortfalls in emergency situations, including currency-specific shortfalls and cash shortfalls in foreign currency (bills). These plans have to consider market and institutional restrictions that may exist under crisis situations. While central banks are the natural providers of domestic currency liquidity, their capacity to provide liquidity in foreign currencies may be limited, 
and foreign currency liquidity facilities may be unavailable or restricted. While, the issue of currency-specific shortages can normally be solved in foreign exchange markets, these may not be operational under certain circumstances. Moreover, the problem of shortfalls in foreign currency bills is costly to overcome at short notice and under stress. Some central banks of dollarized countries store certain amounts of foreign currency bills, but others may not be willing to assume the costs of storing, shipping, and/or insuring the large amounts of foreign currency bills that could be demanded in a crisis situation. Banks should have clear procedures to solve shortages of foreign currency bills at short notice. Small depositors are more likely to withdraw their deposits in cash, while large creditors are likely to wire them abroad. Therefore banks with a broad deposit base are likely to require proportionally more dollar bills, than banks with a concentrated deposit base. Under systemic crisis scenarios, the strategies should also consider possible limitations of access to key sources of funding (e.g., debt issues in domestic or foreign markets, domestic or foreign interbank funds) and market disturbances affecting the liquidity of markets for domestic assets normally regarded as liquid (e.g., domestic corporate equity or bonds, government paper).

Supervisors should assess the adequacy of banks' liquidity risk strategies, policies and procedures to withstand the types of disturbances that are likely to occur in the financial system in which they operate. In this regard, the supervisory review should examine whether banks' plans, policies, and actions take into account the specific sources of liquidity risk of operating in a dollarized financial system, such as currency-induced credit risk, the absence of a lender of last resort and the added potential of systemic liquidity crunches. The review of banks' contingency plans should take into account the adequacy of the banks' strategy to address shortfalls of foreign currency liquid assets and foreign currency cash. The supervisory assessment of banks' exposure to liquidity risks, should take into account liquidity risks derived from currency-induced credit risks. Based on this assessment, supervisors should require corrective measures as necessary, including changes to liquidity risk management policies and practices, additional holdings of liquid assets or lower maturity mismatches, and reduction of exposure to liquidity risks stemming from currency-induced credit risk.

\section{A buffer for liquidity risks}

Systemic liquidity risks associated with foreign currency deposits, and banks' tendency to underprice them, create a need to have a buffer to protect individual banks and the banking system. There is tension between banks and monetary authorities as to who pays for the costs of holding high foreign currency liquid assets. In dollarized financial systems, most banks - if left alone - will hold fewer liquid assets than necessary to withstand likely shocks, expecting that the monetary authority will provide needed liquidity assistance. In this context, minimum liquidity or reserve requirements are preferred to more market-based measures, such as limits on maturity gaps. Limits on maturity gaps are more risk sensitive and, as they allow banks more freedom on how to manage their liquidity, are also less costly than liquidity (or reserve) requirements, and, hence, could be preferable to control liquidity risks in most financial systems. However, they are unlikely to provide an adequate buffer to protect banks and the financial system from liquidity risks in dollarized systems. First, they 
depend on bank assumptions about creditor and debtor behavior and, in particular about the liquidity of assets and liabilities. Second, under a systemic liquidity crisis, assets that are normally liquid may not be so liquid, and liabilities that are normally stable may not be so stable. This is particularly true if early withdrawal of time deposits and other liabilities is possible. Thus, under a systemic liquidity crisis, liquid assets may be used to repay obligations of a wide maturity range.

Currency specific minimum liquidity (or reserve) requirements could be used to account for the higher liquidity risks of foreign currency liabilities. To ensure that banks internalize these risks, required foreign currency liquid assets should be held in foreign currency and their rates may be set higher than domestic currency requirements. The specific design of the minimum requirements has to be tailored to the needs of each particular country. However, the following general considerations should be noted:

- $\quad$ Liquid assets eligible to comply with these requirements should be liquid even under stressful market conditions. In some countries this restricts the range of eligible assets to cash, deposits at the central bank, and liquid deposits in investment grade financial institutions abroad. In others, the range of liquid assets could be somewhat wider. If pressures are likely to mount to use central bank international reserves for other purposes (e.g., fiscal), it may be advisable to have liquidity requirements, instead of reserve requirements. In turn, if there are difficulties in ensuring that bank liquid assets are in fact liquid (e.g., they may be pledged as collateral for bank operations), reserve requirements may be preferable. An alternative option would be to set up a trust fund abroad, with the sole purpose of being used as collateral for central bank facilities to the contributing banks. The trust fund would be protected from both pressures to divert it for fiscal purposes and the possibility that risk-prone banks elude liquidity requirements by pledging their liquid assets.

- The liability base should include the broadest range of liabilities likely to be volatile under stressful market conditions. This reduces the scope for arbitraging the regulation by booking some liabilities so that they are excluded from the minimum requirements.

- When setting the minimum rates, authorities would have to assess the costs of these requirements against the benefits of the insurance they provide by protecting the financial system from potential shocks. Insuring against all possible shocks would not be desirable as the excessive costs would encourage regulatory arbitrage. An example of a simplified way in which the costs and benefits of these requirements can be assessed is presented in Box 3. 


\section{Box 3. Costs and Benefits of Prudential Requirements to Control Liquidity Risk: The Case of Peru}

This box estimates the costs and benefits of two overlapping prudential requirements used in Peru to control liquidity risks: reserve requirements and liquidity requirements.

\section{Prudential Norms}

Reserve requirements: Required reserves are held as vault cash or deposits at the central bank in the deposits currency denomination. In addition to a 6 percent non-remunerated reserve requirement applied to all deposits, foreign currency deposits (FCDs) are subject to 30 percent marginal reserve requirement (down from 45 percent in 1998, but up from 20 percent in early 2004). This regulation was recently modified to subject more credits from banks abroad to reserve requirements. Thus, average required reserves on FCDs are currently 29.5 percent. The central bank pays a fixed rate of 2.25 percent on foreign currency reserves above the 6 percent level.

Liquidity requirements: Banks are required by the supervisory authorities to hold liquid assets equivalent to at least 8 percent and 20 percent of all their liabilities maturing during the next 12 months, in domestic currency and foreign currency, respectively. Eligible assets include vault cash, deposits at the central bank, central bank certificates of deposit, deposits in first-rate foreign banks, and investments in securities negotiated in centralized markets and rated as investment grade by international agencies.

\section{Costs}

Both liquidity and reserve requirements affect banks' profits, as liquid prime assets normally earn lower returns than less liquid assets and reserve requirements are remunerated as below market rates. Assuming that, in the absence of liquidity or reserve requirements, banks would only hold liquid assets equivalent to 5.5 percent of local currency liabilities and 3.6 percent of foreign currency liabilities, costs would amount to 1.60 percent of liabilities in foreign currency (1.5 percent for reserve requirements and 0.7 percent for liquidity requirements) and 0.45 percent of liabilities in domestic currency $(0.2$ for reserve requirements and 0.4 percent for liquidity requirements).

\section{Benefits}

The marginal contribution of the liquidity and reserve requirements to limiting liquidity risk can be estimated by subtracting the liquid assets that banks would hold voluntarily from the required liquid assets, which amounts to 15 percent of total bank liabilities. This figure is substantially above the maximum run experienced by the Peruvian banking system from 1993 to June 2002 (maximum losses for the banking system range from 2.0 percent to 8.3 percent). However, since runs have been generally accompanied by some flight to quality, this buffer would not protect against — and perhaps should not be expected to protect against — the largest run at the individual bank level.

- As a prudential tool, these requirements should not be set to unduly tax banks' operations or to create a captive demand for government debt. If liquid assets are required to be held in the form of central bank liabilities - such as deposits at the central bank or central bank securities - these should pay market interest rates.

\section{Implementation Issues}

The implementation of the proposed framework to strengthen the supervisory framework for dollarized financial systems would give rise to a number of challenges for bank supervisors. 
How, when, and to what extent the above-mentioned adaptations should be implemented are not easy decisions. The specific characteristics of the financial system, the economy in which it operates, and the market infrastructure and institutions have to be taken into account. The following questions are at the center of the decision process:

- Who needs this framework anyway?

- How much risk reduction is desirable?

- What is the best sequence of implementation for the financial system?

- How can regulatory arbitrage be avoided?

- Is the implementation of this framework independent of the actions of other national authorities? Or should it be regarded as part of a broader national plan to reduce the vulnerabilities from dollarization, and therefore, be coordinated with other authorities, such as fiscal or monetary authorities?

- How can these measures be integrated into the broader plans of supervisory and regulatory improvements?

There is no unique dollarization threshold beyond which countries should implement the proposed measures. It is important to note that these recommendations are not to be regarded as an all-or-nothing package. Some countries may need all of them, others may need some of them, yet others may need none. Clearly, countries with dollarization levels above 50 percent, or with somewhat lower but increasing levels of dollarization, should seriously consider the risks discussed in this paper. On the other hand, countries with dollarization levels below 15 percent need not invest resources in adapting their supervisory frameworks. In many countries, however, it may not be easy to decide if it is worth investing time and resources to insure against risks that may or may not materialize. The recommendation for those countries in the gray area is to first gather information that will allow an assessment of their exposure to these risks. Stress tests, such as the ones presented in Appendix II, can assist the authorities in determining how sensitive the solvency and liquidity of their financial systems are to an exchange rate depreciation and other market disruptions associated with dollarization. In some countries, high exposure to dollarization risks could be concentrated on one business segment, such as mortgage or consumer loans, and so it would be best to address these risks separately.

The costs of controlling the risks of dollarization could be high for highly dollarized financial systems. In fact, the costs of implementing the proposed measures would be high if the risks that need to be addressed are also high. The measurement of the additional risks from dollarization, the estimated risk reduction achieved by a specific prudential measure and its costs are key for the design of prudential requirements. How much protection against the risks of dollarization is desirable has to be gauged against the costs of this protection. Calculations such as the ones presented in Boxes 2 and 3 could be of assistance for this 
purpose. The objective of these prudential requirements cannot be to eliminate all risks, as the enormous costs would create huge incentives for arbitrage. In some cases, a carefully phased implementation would be necessary to achieve the desired risk reduction without making the business unprofitable. A road map for implementation needs to be tailored to the specific needs, the level of bank supervision, and the condition of the banking system of each particular country.

While the optimal sequence of implementation cannot be defined independently of the country's institutions, supervisory framework, and the condition of its financial system, there are two general recommendations:

- $\quad$ Currency-induced credit risk is a specific type of credit risk. Supervisory measures that attempt to address this risk, without having addressed the more general weaknesses of overall credit risk management, are not likely to prevent the next financial crisis. More precisely, if banks do not have adequate overall credit risk management, they are unlikely to have good currency-induced credit risk management.

- $\quad$ Better disclosure of risk exposures and management policies can promote market discipline; however, when applied in vulnerable financial systems and weak risk management, it could also create confidence problems. The timing of disclosure requirements has to be carefully considered to prevent this from happening.

Tightening prudential regulation in the banking system may create incentives for regulatory arbitrage. Banks could be induced to transfer risks to, or register transactions in, other entities - domestic or foreign - that are not subject to the new prudential requirements. In designing these measures, authorities should try to reduce the scope for regulatory arbitrage. This is particularly important when designing provisioning or capital requirements, minimum liquidity requirements, and limits or prohibitions on certain mismatches or transactions. Changes may need to be accompanied by measures geared at avoiding circumvention of such regulations. For instance, supervisors should be aware that tightening norms on currencyinduced credit risk may lead banks to increase intermediation in local currency with much shorter maturities, trading one risk for another (i.e., when long term projects are financed with short term domestic currency loans, the currency-induced credit risk is traded by a direct credit risk). The possibility of increasing risks in the domestic currency loan portfolio should not be overlooked. Also, whenever possible, the regulations should be applied to all members of a conglomerate. For this purpose, effective consolidated supervision is necessary. It is noted, however, that in some of the countries surveyed, consolidated supervision of conglomerates is incomplete and ineffective. Moreover, authorities may lack the power to impose prudential requirements beyond the domestic borders, particularly if the cross-border members of the conglomerate are not branches of the domestic bank. Additionally, regulatory arbitrage is not a static problem. In fact, the effectiveness of some measures may erode over time as banks find ways to elude their costs, and thus supervisors should often review them to ensure their continued effectiveness. 
The recommendations discussed in this paper can be easily integrated into the current improvement plans of most supervisory agencies. The proposed adaptations to the supervisory framework are based on the Basel I framework, but are also consistent with a transition towards Basel II. In fact, being in compliance with Basel Core Principles for Effective Banking Supervision and implementing other elements of the Basel I or Basel II supervisory framework would help to improve the effectiveness of the proposed measures.

Since prudential supervision can only mitigate some of the risks arising from dollarization, prudential measures may need to be part of a broader medium-term plan designed to promote the use of the domestic currency. The plan would include measures such as: keeping inflation low, removing administrative ceilings on interest rates, reducing high unremunerated reserve requirements for local currency deposits, developing markets for local currency-denominated public securities, and improving the efficiency of the payments system. ${ }^{19}$ While most of the prudential measures to strengthen the supervisory framework could be implemented independently of other national authorities, coordination between monetary and prudential authorities is advisable to improve the effectiveness of their plans.

${ }^{19}$ For a detailed presentation of these issues, please refer to: Gulde et.al. (2004). 


\section{COUNTRY Practices: SuRVey Results}

This section explores current supervisory practices to control the risks stemming from banks' foreign currency activities. It is based on a survey conducted between June and September 2004, in 17 countries of diverse level of economic development and regions across the world. ${ }^{20}$ The level of financial dollarization ${ }^{21}$ of the countries surveyed is also diverse, including six countries with more than half of total deposits in foreign currency (Bolivia, Croatia, Lebanon, Peru, Singapore and Uruguay), six countries with dollarization levels between 30 and 50 percent (Costa Rica, Honduras, Latvia, Romania, Slovenia and Turkey) and five countries with low levels of dollarization (Argentina, Brazil, Chile, Poland, and Sweden).

\section{A. Foreign Exchange Risk}

Traditionally, prudential regulation on foreign exchange exposures has been based on limiting banks' foreign currency exposures. More recently, however, an increasing number of countries are imposing capital requirements against open foreign exchange positions. Requiring capital for foreign exchange exposures, in addition to that required for credit risk, makes it more difficult for weakly capitalized banks to take on new risks. However, capital requirements give a bank greater flexibility in choosing the risks it will accept by allowing managers to allocate a bank's capital between credit and market risk, including foreign exchange risk. ${ }^{22}$

Most countries surveyed have both capital charges and limits on foreign exchange exposures (Table 1). Three countries (Poland, Singapore, and Sweden) have only capital charges on foreign exchange exposures, while six countries have only limits on these exposures (Argentina, Bolivia, Chile, Costa Rica, Honduras and Uruguay). The remaining eight countries have both. Capital charges on foreign exchange risk vary between 8 percent (minimum Basel recommendation) and 12 percent (Lebanon). A special case is Brazil, where the capital requirement is 50 percent of foreign exposures exceeding 5 percent of capital. Some countries (Bolivia and Peru) have asymmetric limits on foreign exchange exposures, whereas others permit structural positions (Lebanon).

\footnotetext{
${ }^{20}$ Four responding countries are members of the European Union (Latvia, Poland, Slovenia and Sweden) and three countries are European, nonEU members (Croatia, Romania, and Turkey). There is also one Asian country (Singapore), one country from the middle east (Lebanon) and eight countries from the western hemisphere region (Argentina, Bolivia, Brazil, Chile, Costa Rica, Honduras, Peru, and Uruguay).

${ }^{21}$ Financial dollarization is measured here as the share of foreign currency deposits over total deposits. The term dollarization is used for all countries, although in some of these countries the foreign currency of choice is not the U.S. dollar, but the Euro.

${ }^{22}$ Abrams and Beato (1998).
} 
Over half of the countries surveyed have specific risk-management guidelines pertaining to foreign exchange risk. In Peru, guidelines are quite specific regarding the methodology for their internal control systems, including Value at Risk, scenario analysis, back testing, and stress testing. In other cases, there are general guidelines on risk management; however, there are no specific guidelines on foreign exchange risk.

\section{B. Credit Risk}

\section{Data collected by supervisory authorities}

Some dollarized countries report collecting debtor information that distinguishes domestic and foreign currency claims (Bolivia, Lebanon, Peru, and Uruguay). Detailed information on the loan portfolio, by debtor or by operation, is generally collected for large exposures. Argentina, Brazil, Chile, Croatia, and Poland, for example, collect individual information for commercial or medium to large debtors, and gather aggregated information at the portfolio level for consumer loans or small companies. Others (Bolivia, Costa Rica, Honduras, Peru, Turkey, Uruguay) gather individual information, also for small exposures.

Four countries (Poland, Costa Rica, Honduras and Uruguay), two of them with low dollarization levels, report having a working definition of unhedged borrower. ${ }^{23}$ However, these are internal definitions of the supervisory agency, not published or shared with financial institutions. Only Costa Rica requires banks to report their exposure to credit risk from unhedged borrowers. Costa Rica reports gathering quarterly information on the capacity of large borrowers to generate a foreign currency cash flow and estimating, as a residual, large borrowers that do not have foreign currency revenues. As of March 2004, 28 percent of all loans in the Costa Rican financial system are estimated to be granted in U.S. dollars to borrowers who do not generate foreign exchange revenue. Other supervisors report using information on debtors' activity and purpose of the loan and on the sector composition of exports and imports to make inferences about banks' exposure to unhedged borrowers (Uruguay). On this basis, it is reported that Uruguayan banks granted 74 percent of their loans to unhedged borrowers in June 2004.

\footnotetext{
${ }^{23}$ For instance, Uruguay considers "borrowers receiving loans in foreign currency, whose cash flow to repay loans are in local currency." Poland regards as unhedged debtor one "that does not have the natural hedging, e.g. cash inflows denominated in foreign currencies, and does not secure his exposure on derivative market." In contrast, Honduras and Costa Rica, have definitions that refer only to the capacity of the debtor to generate foreign currency.
} 




\section{Prudential Rules}

Few countries have implemented prudential rules aimed at controlling banks' exposures to currency-induced credit risk. None of the responding countries report using higher capital requirements for foreign currency assets, relative to domestic currency assets. ${ }^{24}$ However, some highly dollarized countries have capital requirements that are higher than the 8 percent minimum CAR recommended by the BCBS (Figure 1). Only one country (Peru) reports requiring higher provisions for foreign currency loans relative to domestic currency ones. In addition to Peru, five other countries (Singapore, Poland, Lebanon, Argentina, and Chile) report that banks are expected to assign a higher risk rating to debtors whose capacity to repay is sensitive to exchange rate movements, in the context of their overall risk assessment of borrowers.

Figure 1. Financial Dollarization vs. Capital Requirements for Selected Countries, 2004 /1

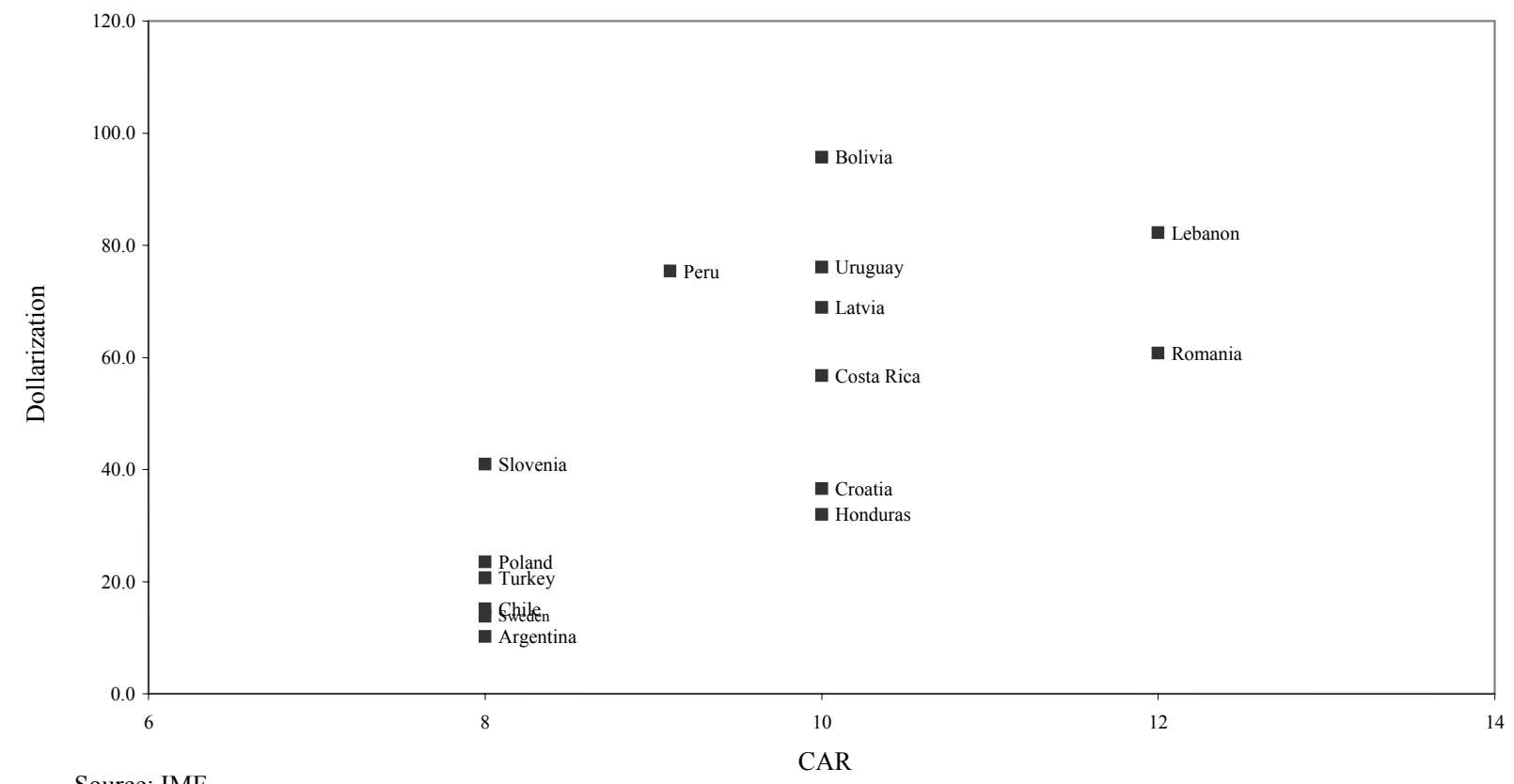

Source: IMF.

1/ Capital requirement ranges from 8 to 10 for Argentina and from 8 to 12 for Slovenia Foreign currency loan data not available for Brazil and Singapore. The information on FCDs for Lebanon is as of 2003.

\footnotetext{
${ }^{24}$ In Uruguay, higher capital requirements for foreign currency loans are to become effective in July 2006, by establishing a $125 \%$ weight on these assets. A similar approach has been adopted by Georgia, a country not in the survey, where a 200 percent risk weight is applied for foreign currency assets for the calculation of the minimum required capital to risk weighted assets ratio.
} 
Limits or other restrictions are used by some countries with low degrees of dollarization (Brazil, Chile, and Honduras) and by Argentina, formerly highly dollarized until the legal pesification (see Table 2). For instance, Brazil prohibits banks to grant loans in foreign currencies, but allows foreign-currency-indexed loans. Chile requires that banks approve and report to the superintendency, internal policies for the management of these credits prior to engaging in this type of business. Honduras has a limit of 15 percent of foreign currency deposits that can be allocated to grant foreign currency loans to nonexporters. Argentina's current legal framework ${ }^{25}$ stipulates that funds from foreign currency deposits should be allocated to foreign trade related financing, inter-financial loans or central bank bills. In case of misallocation, there is an increase of liquidity requirements deposited at the central bank.

Table 2. Credit Risk Prudential Regulations for Selected Countries

\begin{tabular}{|c|c|c|c|c|c|c|c|c|c|}
\hline \multirow[b]{2}{*}{ Country } & \multicolumn{2}{|c|}{$\begin{array}{l}\text { Capital requirements } \\
\text { for credit risk }\end{array}$} & \multicolumn{7}{|c|}{ Specific rules for credit risk exposures to unhedged borrowers } \\
\hline & $\begin{array}{c}\text { Capital } \\
\text { requirements }\end{array}$ & Type 1/ & $\begin{array}{l}\text { Higher } \\
\text { capital } \\
\text { requirements }\end{array}$ & $\begin{array}{c}\text { Higher } \\
\text { provisions }\end{array}$ & $\begin{array}{c}\text { Higher } \\
\text { generic } \\
\text { provisions }\end{array}$ & $\begin{array}{c}\text { Limits or } \\
\text { prohibitions }\end{array}$ & $\begin{array}{c}\text { Hedging } \\
\text { requirements }\end{array}$ & $\begin{array}{c}\text { Higher } \\
\text { risk rating } \\
\text { expected }\end{array}$ & $\begin{array}{l}\text { Approval } \\
\text { of policies } \\
\text { and inform } \\
\text { Supervisor } \\
\text { y agency }\end{array}$ \\
\hline Argentina & 8 to 10 & $\mathrm{I} \& \mathrm{C}$ & $\mathrm{N}$ & $\mathrm{N}$ & $\mathrm{N}$ & $\mathrm{Y}$ & $\mathrm{N}$ & $\mathrm{Y}$ & $\mathrm{N}$ \\
\hline Bolivia & 10 & I & $\mathrm{N}$ & $\mathrm{N}$ & $\mathrm{N}$ & $\mathrm{N}$ & $\mathrm{N}$ & $\mathrm{N}$ & $\mathrm{N}$ \\
\hline Brazil & 11 & $\mathrm{C}$ & $\mathrm{N}$ & $\mathrm{Y}$ & $\mathrm{N}$ & Y & $\mathrm{N}$ & $\mathrm{N}$ & $\mathrm{N}$ \\
\hline Chile & 8 & $\mathrm{C}$ & $\mathrm{N}$ & $\mathrm{N}$ & $\mathrm{N}$ & $\mathrm{N}$ & $\mathrm{N}$ & Y & $\mathrm{Y}$ \\
\hline Costa Rica & 10 & I & $\mathrm{N}$ & $\mathrm{N}$ & $\mathrm{N}$ & $\mathrm{N}$ & $\mathrm{N}$ & $\mathrm{N}$ & $\mathrm{N}$ \\
\hline Croatia & 10 & I \& C & $\mathrm{N}$ & $\mathrm{N}$ & $\mathrm{N}$ & $\mathrm{N}$ & $\mathrm{N}$ & $\mathrm{N}$ & $\mathrm{N}$ \\
\hline Honduras & 10 & I & $\mathrm{N}$ & $\mathrm{N}$ & $\mathrm{N}$ & Y & $\mathrm{N}$ & $\mathrm{N}$ & $\mathrm{N}$ \\
\hline Latvia & 10 & I \& C & $\mathrm{N}$ & $\mathrm{N}$ & $\mathrm{N}$ & $\mathrm{N}$ & $\mathrm{N}$ & $\mathrm{N}$ & $\mathrm{N}$ \\
\hline Lebanon & 12 & C & $\mathrm{N}$ & $\mathrm{N}$ & $\mathrm{N}$ & $\mathrm{N}$ & $\mathrm{N}$ & Y & $\mathrm{N}$ \\
\hline Peru & 9.1 & I \& C & $\mathrm{N}$ & $\mathrm{Y}$ & $\mathrm{Y}$ & $\mathrm{N}$ & $\mathrm{N}$ & $\mathrm{Y}$ & $\mathrm{N}$ \\
\hline Poland & 8 & I \& C & $\mathrm{N}$ & $\mathrm{N}$ & $\mathrm{N}$ & $\mathrm{N}$ & $\mathrm{N}$ & Y & $\mathrm{N}$ \\
\hline Romania & 12 & C & $\mathrm{N}$ & $\mathrm{N}$ & $\mathrm{N}$ & $\mathrm{N}$ & $\mathrm{N}$ & $\mathrm{N}$ & $\mathrm{N}$ \\
\hline Singapore & 10 & I \& C & $\mathrm{N}$ & $\mathrm{N}$ & $\mathrm{N}$ & $\mathrm{N}$ & $\mathrm{N}$ & Y & $\mathrm{N}$ \\
\hline Slovenia & 8 to 12 & I \& C & $\mathrm{N}$ & $\mathrm{N}$ & $\mathrm{N}$ & $\mathrm{N}$ & $\mathrm{N}$ & $\mathrm{N}$ & $\mathrm{N}$ \\
\hline Sweden & 8 & I \& C & $\mathrm{N}$ & $\mathrm{N}$ & $\mathrm{N}$ & $\mathrm{N}$ & $\mathrm{N}$ & $\mathrm{N}$ & $\mathrm{N}$ \\
\hline Turkey & 8 & I \& C & $\mathrm{N}$ & $\mathrm{N}$ & $\mathrm{N}$ & $\mathrm{N}$ & $\mathrm{N}$ & $\mathrm{N}$ & $\mathrm{N}$ \\
\hline Uruguay & 10 & $I \& C$ & $\mathrm{~N}$ & $\mathrm{~N}$ & $\mathrm{~N}$ & $\mathrm{~N}$ & $\mathrm{~N}$ & $\mathrm{~N}$ & $\mathrm{~N}$ \\
\hline
\end{tabular}

Source: IMF.

1/ Applicable on a individual (I) or consolidated ( C) basis.

${ }^{25}$ Article $23^{\text {rd }}$ of Decree $905 / 02$ and related central bank regulations. 


\section{Supervisory guidelines}

Six of the surveyed countries have explicitly required banks to manage and control their currency-induced credit risk. For instance, in Lebanon and Peru, banks are required to gather data and perform an analysis that allows them to assess the extent of their borrowers' exposure to a currency depreciation. General guidelines recommend that banks assess the borrower's ability to generate foreign currency cash flow to hedge against a possible change in the exchange rate. In Poland, the General Inspector of Banking Supervision has issued guidance letters on the management of risks stemming from foreign currency lending.

Few countries conduct regular stress testing to estimate banks' exposure to credit risks derived from borrowers' currency, interest rates or maturity mismatches (See Table 3). Peru requires financial institutions to conduct annual stress tests to measure the impact of a 10 percent and 20 percent depreciation of the domestic currency on the repayment capacity of debtors in the loan portfolio. Uruguay and Romania also report conducting some stress tests to measure the impact of a currency depreciation on the loan portfolio, but these do not appear to be done on a regular basis. None of the responding countries report having conducted stress tests to measure banks' exposure to credit risk derived from borrowers' interest rates or maturity mismatches. However, four countries perform scenario analysis measuring the impact of changes in several macroeconomic variables on banks' balance sheets, including, among others, changes in exchange rates, interest rates, inflation and GDP growth (Lebanon, Poland, Singapore, and Lebanon). In Singapore ${ }^{26}$ and Slovenia the supervisory authority has issued recommendations for banks to conduct these tests. In contrast, in Poland and Lebanon these stress tests are mandatory for banks. ${ }^{27}$

\section{Supervisory assessment and preventive action}

Banks' credit risk management policies and practices are generally examined during on-site examinations. In this process, some countries report assessing the overall credit risks of banks (Croatia, Poland, Slovenia, Lebanon, Honduras) and others report conducting a specific assessment of the exposures to credit risk from foreign currency loans to unhedged borrowers (Singapore, Lebanon and Uruguay). In Singapore, the supervisory authorities perform independent assessments of banks' exposure to credit risk from foreign currency loans during both off-site review and the on-site examination process. In Lebanon, for large borrowers (with facilities exceeding 15 percent of the bank's capital, or USD 5 million,

\footnotetext{
${ }^{26}$ Monetary Authority of Singapore (MAS) technical paper on Credit Stress Testing outlines several hypothetical and historical scenarios related to foreign exchange rate changes.

${ }^{27}$ Though some countries require banks to disclose to the public their credit policies and, in general, the major risks that they are exposed to, there is, however, no specific requirement to disclose credit risks emerging from lending to unhedged borrowers.
} 
whichever is less), this assessment includes credit risk from foreign currency loans to unhedged borrowers. Uruguay makes a general classification of a bank loan portfolio in tradable vs. nontradable sector, and analyzes the portion of loans in the nontradable sector that are denominated in foreign currency.

Most countries report that hedging instruments are available in their markets for borrowers to hedge against foreign currency risks, however the extent of their use by borrowers is not known. Only a few countries have very active markets (Singapore, Sweden, Poland and Brazil) with a wide variety of available instruments. Most of them have shallow markets, with one or two main instruments offered, mostly forward contracts with the exchange rate as the underlying variable (Croatia, Romania, Slovenia, Lebanon, and Peru).

Table 3. Credit Management and Stress Testing Practices

\begin{tabular}{|c|c|c|c|c|c|c|c|c|}
\hline \multirow[b]{2}{*}{ Country } & \multicolumn{2}{|c|}{ Supervisory Guidelines } & \multicolumn{6}{|c|}{ Stress Tests } \\
\hline & $\begin{array}{c}\text { Credit risk } \\
\text { management } \\
\text { guidelines }\end{array}$ & \begin{tabular}{|c} 
Guidelines on \\
managing credit \\
risk of borrowers \\
currency \\
mismatches \\
\end{tabular} & $\begin{array}{l}\text { Stress tests for } \\
\text { credit risk from } \\
\text { borrowers' } \\
\text { currency } \\
\text { mismatches } \\
\end{array}$ & \begin{tabular}{|c|} 
Supervisory \\
guidelines for the \\
stress tests
\end{tabular} & $\begin{array}{c}\text { Stress tests for } \\
\text { credit risk from } \\
\text { borrowers' } \\
\text { interest rate } \\
\text { mismatches } \\
\end{array}$ & $\begin{array}{c}\text { Stress tests for } \\
\text { credit risk from } \\
\text { other market } \\
\text { variables }\end{array}$ & $\begin{array}{c}\text { Scenario stress tests } \\
\text { (simultaneous } \\
\text { shocks: i.e., GDP, } \\
\text { reduced credit } \\
\text { access) }\end{array}$ & $\begin{array}{c}\text { Disclosure } \\
\text { requirements on } \\
\text { credit risk } \\
\text { exposures to } \\
\text { unhedged } \\
\text { borrowers } \\
\end{array}$ \\
\hline Argentina & $\mathrm{Y}$ & $\mathrm{Y}$ & $\mathrm{N}$ & $\mathrm{N}$ & $\mathrm{N}$ & $\mathrm{N}$ & $\mathrm{N}$ & $\mathrm{N}$ \\
\hline Bolivia & $\mathrm{Y}$ & $\mathrm{N}$ & $\mathrm{N}$ & $\mathrm{N}$ & $\mathrm{N}$ & $\mathrm{N}$ & $\mathrm{N}$ & $\mathrm{N}$ \\
\hline Brazil & $\mathrm{N}$ & n.a. & n.a. & n.a. & $\mathrm{N}$ & $\mathrm{N}$ & n.a. & n.a. \\
\hline Chile & $\mathrm{N}$ & $\mathrm{N}$ & $\mathrm{N}$ & $\mathrm{N}$ & $\mathrm{N}$ & $\mathrm{N}$ & $\mathrm{N}$ & $\mathrm{N}$ \\
\hline Costa Rica & $\mathrm{N}$ & $\mathrm{N}$ & $\mathrm{N}$ & $\mathrm{N}$ & $\mathrm{N}$ & $\mathrm{N}$ & $\mathrm{N}$ & $\mathrm{N}$ \\
\hline Croatia & $\mathrm{N}$ & $\mathrm{N}$ & $\mathrm{N}$ & $\mathrm{N}$ & $\mathrm{N}$ & $\mathrm{N}$ & $\mathrm{N}$ & $\mathrm{N}$ \\
\hline \multirow{3}{*}{$\begin{array}{l}\text { Honduras } \\
\text { Latvia } \\
\text { Lebanon }\end{array}$} & $\mathrm{N}$ & $\mathrm{N}$ & $\mathrm{N}$ & $\mathrm{N}$ & $\mathrm{N}$ & $\mathrm{N}$ & $\mathrm{N}$ & $\mathrm{N}$ \\
\hline & $\mathrm{Y}$ & $\mathrm{N}$ & $\mathrm{N}$ & $\mathrm{N}$ & $\mathrm{N}$ & $\mathrm{N}$ & $\mathrm{N}$ & $\mathrm{Y}$ \\
\hline & $\mathrm{Y}$ & Y & Y & Y & $\mathrm{N}$ & $\mathrm{N}$ & Y & Y \\
\hline \multirow{3}{*}{$\begin{array}{l}\text { Peru } \\
\text { Poland } \\
\text { Romania }\end{array}$} & $\mathrm{Y}$ & $\mathrm{Y}$ & $\mathrm{Y}$ & Y & $\mathrm{N}$ & $\mathrm{N}$ & $\mathrm{N}$ & $\mathrm{N}$ \\
\hline & $\mathrm{Y}$ & $\mathrm{Y}$ & $\mathrm{Y}$ & $\mathrm{Y}$ & $\mathrm{N}$ & $\mathrm{N}$ & Y & $\mathrm{N}$ \\
\hline & $\mathrm{N}$ & $\mathrm{N}$ & Y & $\mathrm{N}$ & $\mathrm{N}$ & $\mathrm{N}$ & Y & $\mathrm{N}$ \\
\hline \multirow{2}{*}{$\begin{array}{l}\text { Singapore } \\
\text { Slovenia }\end{array}$} & $\mathrm{Y}$ & $\mathrm{Y}$ & $\mathrm{Y}$ & $Y$ & $\mathrm{~N}$ & $\mathrm{~N}$ & Y & $\mathrm{N}$ \\
\hline & $\mathrm{Y}$ & $\mathrm{N}$ & $\mathrm{Y}$ & $\mathrm{N}$ & $\mathrm{N}$ & $\mathrm{N}$ & Y & $\mathrm{N}$ \\
\hline \multirow{2}{*}{ Sweden } & $\mathrm{Y}$ & n.a. & n.a. & n.a. & $\mathrm{N}$ & $\mathrm{N}$ & Y & n.a. \\
\hline & $\mathrm{Y}$ & $\mathrm{N}$ & $\mathrm{N}$ & $\mathrm{N}$ & $\mathrm{N}$ & $\mathrm{N}$ & $\mathrm{N}$ & $\mathrm{N}$ \\
\hline $\begin{array}{l}\text { Turkey } \\
\text { Uruguay }\end{array}$ & $\mathrm{Y}$ & $\mathrm{Y}$ & $\mathrm{Y}$ & $\mathrm{N}$ & $\mathrm{N}$ & $\mathrm{N}$ & $\mathrm{N}$ & $\mathrm{N}$ \\
\hline
\end{tabular}

Source: IMF.

Most dollarized countries surveyed report that banks appear not to be pricing the foreign currency risk derived from unhedged currency mismatches (Croatia, Slovenia, Turkey, Honduras, and Uruguay). Banks tend to operate under the assumption that the authorities will keep the current exchange rate regime. The fact that this could be very costly and may not always be true fails to be priced in. Uruguay explicitly mentions this as a problem, and 
reports seeking to discourage this behavior by requiring banks to take this mismatch into consideration when rating and provisioning borrowers. Four countries (Singapore, Sweden, Lebanon and Costa Rica) report that interest rates charged by banks are a function of the overall risk of the borrower, which may include risks associated with the sensitivity of their capacity to repay in the event of exchange rate movements. In turn, three countries (Latvia, Poland and Romania) report that they have specifically identified that banks charge higher interest rates to borrowers with currency mismatches.

\section{Liquidity Risk}

\section{Data collected by supervisory authorities}

Fourteen of the seventeen countries report collecting some information on liquidity risks on a currency specific basis. Eleven of these collect information on maturity mismatches in each of the currencies that are significantly important, including three countries with low financial dollarization. Some countries collect reports on maturity mismatches based on contractual maturity and adjusted behavior profiling (Singapore and Chile), others do it based on adjusted behavior only (Peru) (Table 4).

\section{Prudential rules}

Measures have been taken to reduce the vulnerabilities of financial systems to liquidity risks that could arise from financial dollarization. The specific modalities of these arrangements vary across countries; though countries commonly utilize a combination of prudential measures. The most common combination is that of minimum liquidity ratios and reserve requirements. Some dollarized countries have high minimum requirements to build a buffer for liquidity risks. Others also apply higher requirements for foreign currency relative to domestic currency liabilities.

All the countries surveyed have minimum reserve requirements, with the exception of Sweden, and nine of them have also minimum liquidity ratios. The design of these instruments varies, though typically most countries require that liquid assets are held in the same currency as the liabilities they are expected to cover. Some countries apply higher rates for shorter maturity liabilities (Bolivia, Brazil, Chile, and Uruguay) and others require higher rates for foreign currency deposits relative to domestic currency ones (Romania, Turkey, Lebanon, Argentina, Bolivia, Peru, and Uruguay). A combination of average and marginal reserve requirements (Croatia and Peru) is used by some countries. For instance, in Peru there is a 30 percent marginal reserve requirement for all foreign currency deposits and some liabilities with foreign financial institutions. Reserve requirements are compensated in most countries, albeit usually at below-market interest rates. Some countries have established minimum liquidity requirements that apply only to foreign currency liabilities (Croatia, Slovenia, and Honduras).

Four countries (Romania, Slovenia, Chile, and Honduras) impose limits on maturity mismatches of banks' assets and liabilities and one (Argentina) is considering imposing such 
a limit. In all these cases, the limits appear to be defined in terms of residual contractual maturities. Limits can be defined for one or two particular time buckets, as in Slovenia, Chile and Honduras, or for all time buckets on a cumulative basis, as in Romania. All of these countries define limits for the overall mismatches of domestic and foreign currencies. However, two countries set an independent limit — for one currency only — on the mismatch for the 30 days time band: foreign currency in Chile and domestic currency in Honduras.

\section{Supervisory guidelines}

Most countries have issued regulations or some sort of supervisory guidelines requiring banks to set appropriate policies and practices to manage liquidity risks. Some countries (Croatia) have issued these in the context of general risk management rules. Others (Slovenia and Bolivia) have issued specific regulations on liquidity risks. Only two countries (Latvia and Lebanon) have set explicit recommendations to manage foreign currency liquidity risks. In Lebanon, for instance, the "Generic Risk Management Manual" includes specific requirements to assess any form of mismatch in each foreign currency, determine alternative sources of financing, and consider committed lines of credit in foreign currencies.

In nine of the seventeen countries, banks are required to use stress testing techniques to estimate the impact of market and other changes on their liquidity. Some regulators have explicit requirements for these stress tests. For instance, in Singapore, banks are required to examine their cash flows under bank-specific crisis and general market crisis scenarios. In Sweden, the FSA guidelines on these scenarios require banks to measure payments and to analyze liquidity risks for each currency separately where the bank is exposed. In Lebanon, banks are expected to simulate various scenarios considering market changes in terms of currency, instruments, volumes, maturity, rates, and products. In most countries the parameters and specific conditions for these scenarios are to be defined by the banks. An exception is Peru, where the regulation sets an explicit stress scenario for banks to run. In this latter case, while the scenario conditions are equal for both currencies, the liquidity risks are to be assessed independently for each currency.

Contingency plans for adverse liquidity conditions are required in thirteen out of the seventeen countries. Wherever stress testing is required, the plan is generally designed to solve the specific conditions and vulnerabilities identified in the stress scenarios. Most supervisors review contingency plans during the on-site examination process, including Bolivia and Uruguay that have no formal requirements for these plans to be formulated. In Poland, Turkey and Peru, the contingency plans are reviewed during the off-site as well as the on-site supervisory processes. One country (Sweden) restricts this review to the systemically important banks.

\section{Supervisory assessment and preventive action}

Most countries conduct an off-site review of banks' liquidity on the basis of reports submitted by banks, and assess liquidity risk management during on-site examinations. These assessments generally focus on overall liquidity risks, and rarely look into specific aspects 
related to foreign currency operations. An exception is Poland, where supervisors conduct a specific assessment of liquidity risks arising from banks' foreign currency operations for cases in which these are considered significant. In particular, Poland's assessment of risks associated with foreign currency operations, looks into the status and prospects of sources of funding, off-balance-sheet operations impacting liquidity risk levels, the impact of subsidiary cash-flows on the bank's liquidity, and the impact on liquidity of foreign currency-induced credit risk, among others. Besides examining liquidity risks of individual institutions, some supervisors also conduct an assessment of systemic liquidity conditions and risks (Croatia, Lebanon, Brazil, Peru and Uruguay) and in the case of Latvia this assessment is done by the central bank. The Central Bank of Brazil, for instance, conducts system-wide stress tests for all financial institutions in the financial system, identifying vulnerable institutions and their related entities and feeding back these results to bank supervisors, in order to design appropriate corrective actions.

\section{Institutional framework and market conditions}

Under normal conditions, banks have access to a wide variety of sources of funds in foreign currency, but some of these may not be accessible under adverse liquidity conditions. To protect against liquidity risk, some countries with a significant share of foreign currency liabilities, hold high levels of international reserves of the central bank and or commercial financial institutions (Figure 2). While reserves of commercial banks are immediately available to attend to banks' liquidity needs, central bank international reserves are made available through foreign exchange operations or liquidity facilities. Thus, some central banks provide liquidity in foreign currency, under normal or under exceptional circumstances. In six countries liquidity facilities are available only in domestic currency (Singapore, Croatia, Latvia, Argentina, Brazil and Honduras). Lebanon, Bolivia, Chile and Peru have open liquidity facilities in foreign currency that can be accessed regularly by banks. In Lebanon, these include: discount of commercial bills or of foreign currency reserve requirements, repos of Lebanese Eurobonds, overdrafts collateralized with commercial bills, gold or securities, and purchases of bills or government bonds. In Bolivia, the central bank provides liquidity against banks' reserves deposited abroad and through repos of central bank or government securities. In Peru and Chile, liquidity in foreign currency is provided against banks' reserve requirements deposited at the central bank. In Sweden and Slovenia the central bank provides liquidity in foreign currency through currency swaps. Several countries (Sweden, Poland, Lebanon, Costa Rica, Peru, and Uruguay) provide lender of last resort credit in foreign currency against eligible collateral. Eligible collateral can be limited to government or central bank paper and other first class securities. Some countries, however, accept loans as collateral (Sweden, Bolivia, Costa Rica, Peru, and Uruguay). 
Figure 2. Financial Dollarization vs. International Reserves Minus Gold for Selected Countries, 2004

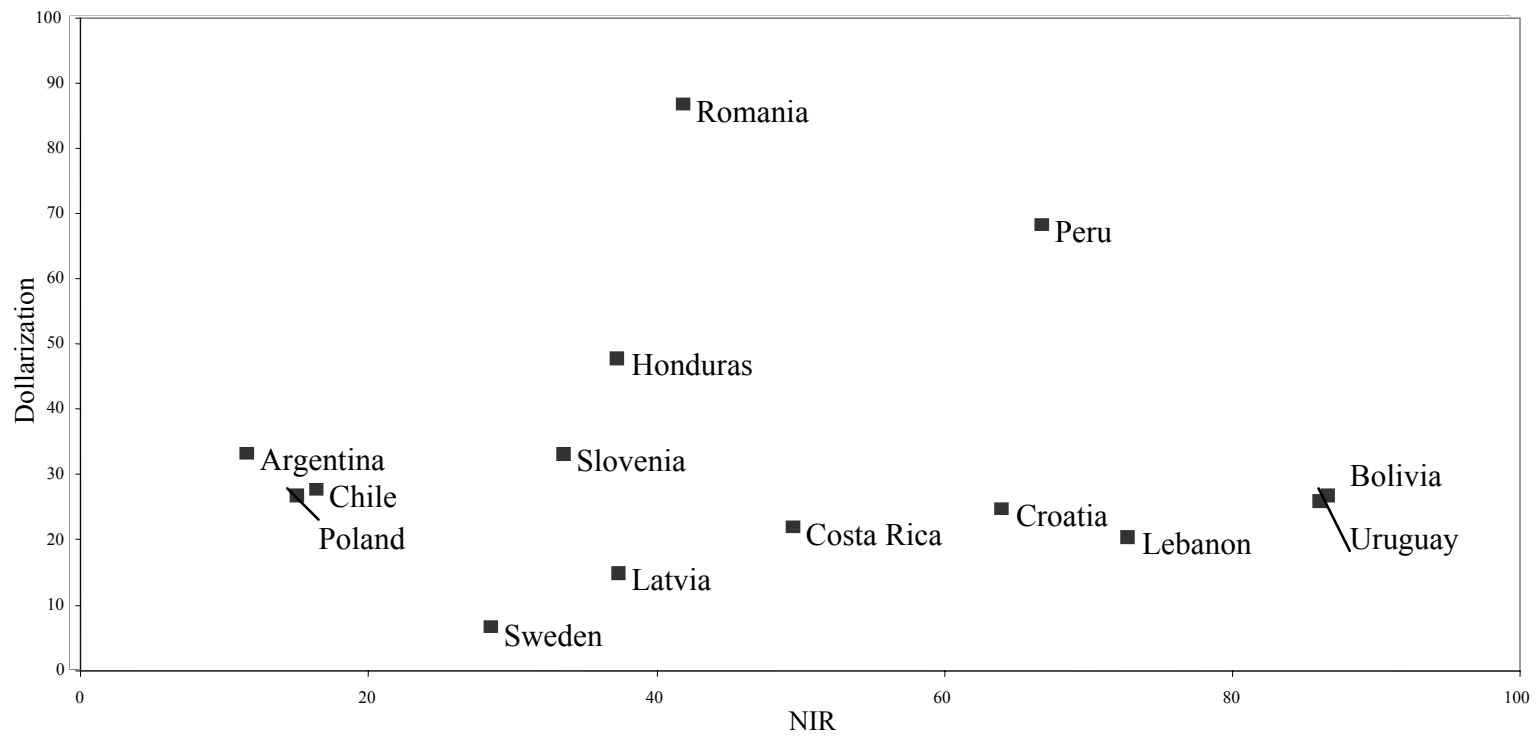

Source: IMF 


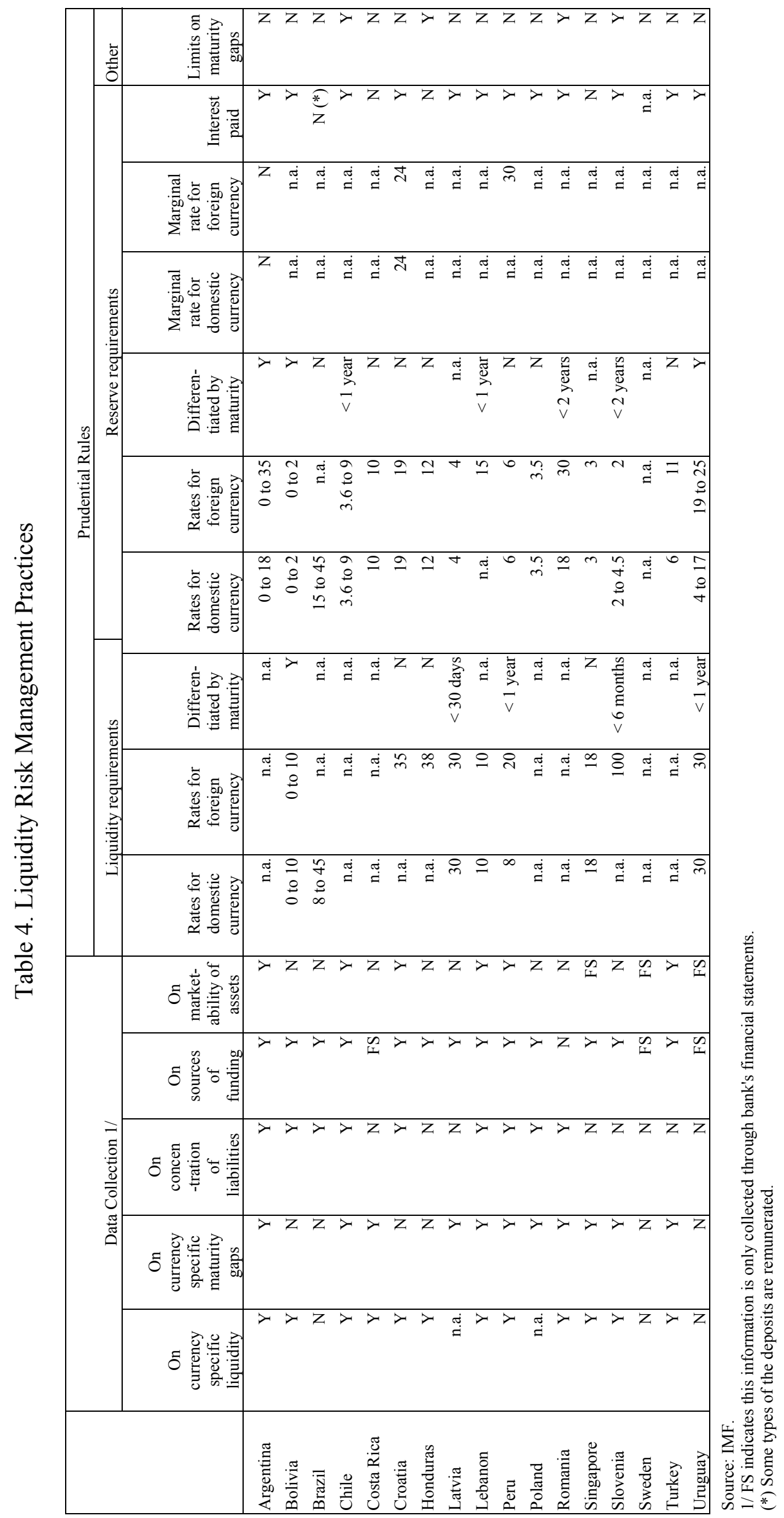




\section{Currency-Induced Credit Risk in Selected BANKIng SystemS}

The purpose of this appendix is to provide a measure of the currency-induced credit risk in selected Latin American and European banking systems. To that end, using aggregate bank data, we estimate a relationship between exchange rate movements and indicators of credit risk, such as the nonperforming loans (NPL) and provisioning ratios.

The econometric estimation of the effect of exchange rate movements on the NPL ratio requires controlling for other macroeconomic variables likely to affect the credit quality of borrowers, including GDP growth, interest rate on bank loans, and inflation. To avoid marked seasonality effects, all the variables are expressed in annual growth rates except for the interest rate where the annual average rate is used. ${ }^{28}$ The choice of a particular dynamicspecification for the regressors was guided by minimizing the sum of the squared errors. For all countries, the preferred specification includes one lag of the independent variables. However a more general dynamic specification, allowing for lags up to one year, was also estimated, with similar results. Hence, given data availability constraints a more parsimonious dynamic specification was chosen. ${ }^{29}$

Table 1 reports the results of the estimation of indirect credit risk for selected countries with publicly available time series information on the ratio of NPLs to total loans. As expected, a depreciation of the domestic currency increases the growth rate of the NPL ratio in Peru, Bolivia, and Poland. However, a depreciation has no statistically significant effect in Brazil, Chile, and Slovakia. In all countries, we found a significant effect of output deceleration and rises in interest rates on the growth of NPLs. To the extent that inflation reduces the real value of loans and facilitates their repayment, a negative relationship is to be expected between inflation and NPL growth. This effect is found statistically significant in Peru; however, for the other countries it is found not to have a significant effect with the exception of Bolivia, where the opposite effect is found. ${ }^{30}$

\footnotetext{
${ }^{28}$ The rationale being that interest rate levels are more relevant than interest rate changes in explaining changes in NPLs and provisions.

${ }^{29}$ The econometric estimates are based on monthly data on NPLs of the banking system, total loans of the banking system, average lending rates, real GDP (when not available, industrial production index was used instead), exchange rate with respect to the US dollar or to Euro (for pre-1999 data, the Euro rate were replaced with Deutsche mark rates). Data were collected from January 1990 to latest observation available for Brazil, Bolivia, Chile, Peru, Poland, and Slovakia. The choice of this particular country set was guided by data availability among those emerging or developing economies with dollarized/eurorized banking systems. In most cases, complete data sets were only available from the mid 1990s. For Bolivia, only quarterly data were available (1990:Q1 - 2004:Q3). For Peru, data on total provisions, foreign currency NPLs and provisions were also collected. All data were downloaded from the International Financial Statistics (IMF), the web pages of the corresponding central banks, supervisory agencies, and national statistical offices.

${ }^{30}$ One possible rationale for the insignificant effect of inflation on NPL growth in Chile (and, to a lesser extent, in Brazil and Poland) could be the use of inflation indexed-contracts.
} 
Table 1. Estimates of Annual NPL Growth Rates in Selected Banking Systems

\begin{tabular}{lcccccc}
\hline & Brazil & Bolivia 1/ & Chile & Peru & Poland & Slovakia \\
\cline { 2 - 6 } Depreciation & -.06 & $6.9^{* *}$ & -.02 & $1.57^{* *}$ & $.47^{* *}$ & -.01 \\
Production growth & $-1.45^{* *}$ & $-7.5^{* *}$ & $-4.73^{* *}$ & $-.91^{*}$ & $-.64^{* *}$ & $-1.13^{*}$ \\
Interest Rate & $1.0^{* *}$ & $3.3^{* *}$ & $.4 .0^{* *}$ & $5.0^{* *}$ & $3.0^{* *}$ & $1.0^{* *}$ \\
Inflation & .60 & $1.5^{*}$ & .49 & $-5.4^{* *}$ & .61 & -.24 \\
& & & & & & \\
Adjusted R2 & .55 & .58 & .67 & .82 & .66 & .30 \\
Observations & $98 / 01-$ & $90: \mathrm{Q} 1-$ & $97 / 02-$ & $94 / 12-$ & $99 / 11-$ & $96 / 01-$ \\
& $04 / 01$ & $04: \mathrm{Q} 3$ & $04 / 10$ & $04 / 09$ & $04 / 04$ & $04 / 09$ \\
\hline
\end{tabular}

Note: Staff own estimates based on monthly data, except for Bolivia where quarterly data are used. “*”, “**” indicate statistical significance at the 90 and 95 percent level respectively, based on Newey-West heteroskedasticity-autocorrelation consistent variance-covariance matrix.

1/ A dummy variable from 1999-2004 is included in the specification for Bolivia to capture structural changes in the economy and the financial system, including the increased foreign bank participation and changes in prudential norms. 31

Alternatively, credit risk in the banking system can be proxied by the ratio of provisions to total loans. Following the same methodology used in the estimation of the annual growth of NPLs we estimate the impact of a depreciation on the annual growth of provision expenditures as a share of loans. Table 2 in column 3 reports the estimation results, which are qualitatively similar to the results of the estimations of the NPL growth rate (information on the ratio of provisions to total loans was only available for Peru).

Disaggregated information on the credit quality of loans by type of currency and by type of loan (i.e. consumer, mortgage, or corporate) allows for a more accurate estimation of the effects of depreciation. The estimated effect of depreciation on the total NPL or provisioning ratio would help predict future effects of devaluation only if the degree of banking system dollarization remains broadly stable. For example, if dollarization has been increasing, future depreciations will have a bigger impact since more borrowers will be negatively affected in the event of a depreciation. Changes in the composition of the banks foreign lending portfolio are also important. Even if the degree of dollarization is stable, when the proportion of consumer and mortgage loans increases, the indirect exchange rate risk is also likely to increase, since retail borrowers are typically unhedged. Table 2 in columns 2 and 4 shows the results for foreign currency NPLs and provisions. The regressors are also modified accordingly by replacing the average lending rate for the lending rate on foreign currency loans. The results are qualitatively similar to those of total NPLs and provisions, yet, as expected, the effect of depreciation turns out to be more pronounced in both cases.

\footnotetext{
${ }^{31}$ A 2004 study by Banco Central de Bolivia on a similar topic (Escobar, 2004) also includes a 1999-2004 dummy to correct for a structural break.
} 
Table 2. Estimates of Annual Provision to Loans Growth Rates in Peru

\begin{tabular}{lrrrr}
\hline & $\begin{array}{c}\text { NPL to } \\
\text { loan ratio }\end{array}$ & $\begin{array}{c}\text { Foreign currency } \\
\text { NPL to foreign } \\
\text { currency loan ratio }\end{array}$ & $\begin{array}{c}\text { Provisions to total } \\
\text { loans ratio }\end{array}$ & $\begin{array}{c}\text { Foreign currency } \\
\text { provisions to foreign } \\
\text { currency loan ration }\end{array}$ \\
\cline { 2 - 5 } Depreciation & $1.57^{* *}$ & $1.95^{* *}$ & $1.32^{* *}$ & $1.90^{* *}$ \\
Production growth & $-.91^{*}$ & $-1.23^{* *}$ & -0.51 & $-0.81^{* *}$ \\
Interest rate & $5.0^{* *}$ & $2.0^{* *}$ & $5.0^{* *}$ & $2.0^{* *}$ \\
Inflation & $-5.4^{* *}$ & $-5.47^{* *}$ & $-5.3^{* *}$ & $-5.14^{* *}$ \\
& & & & .78 \\
Adjusted R2 & .82 & .85 & 0.82 & $94 / 12-04 / 09$ \\
Observations & $94 / 12-04 / 09$ & $94 / 12-04 / 09$ & $94 / 12-04 / 09$ & \\
\hline
\end{tabular}

Note; Staff own estimates.

"*", "***"indicate statistical significance at the 90 and 95 percent level respectively, based on Newey-

West heteroskedasticity-autocorrelation consistent variance-covariance matrix.

The quantitative effect on credit risk of an exchange rate shock varies substantially across countries and appears to be a "threshold effect" related to the degree of dollarization. In particular, Table 3 shows a very large effect for Bolivia - a one percent depreciation leads to a 6.9 percent increase in NPLs. The large effect appears to be related to (i) the large proportion of dollar lending (97 percent of foreign currency loans), (ii) very high corporate debt, and (iii) a relatively low share of tradable goods (especially, when abstracting from hydrocarbon-related exports). Peru also presents a relatively large effect (1.6 percent) as well as a high degree of dollarization (79 percent). In Poland with a moderate dollarization rate, the quantitative impact of depreciation is much less pronounced ( 0.5 percent). In contrast, those countries where the level of dollarization is comparatively low-Brazil (13 percent), Chile (18 percent), Slovakia (13 percent) — an exchange rate shock has no statistically significant effect on credit risk. Also, in most countries, the size of the tradable sector (imperfectly measured by the share of exports in GDP) seems to correlate negatively with the quantitative impact on credit risk. 
Table 3. Effect of a One Percent Exchange Depreciation on the Annual Growth Rates of NPL and Provisioning Ratios

(in percent)

\begin{tabular}{lcccc}
\hline & \multicolumn{4}{c}{$\begin{array}{c}\text { Indicators of Currency Mismatch and } \\
\text { Corporate Leverage }\end{array}$} \\
\cline { 3 - 5 } & $\begin{array}{c}\text { Effect of } \\
\text { ERS on: }\end{array}$ & $\begin{array}{c}\text { Average loan } \\
\text { dollarization }\end{array}$ & $\begin{array}{c}\text { Corporates' } \\
\text { Export/GDP }\end{array}$ & \begin{tabular}{c} 
Debt/Asset \\
\hline Total NPLs
\end{tabular} \\
Brazil 1/ & 0.0 & 13.2 & 10.6 & 33.0 \\
Bolivia & 6.9 & 97.0 & 20.8 & 43.0 \\
Chile 1/ & 0.0 & 17.6 & 30.5 & 30.0 \\
Poland & 0.5 & 22.7 & 27.4 & 17.0 \\
$\quad$ Slovakia 1/ & 0.0 & 12.9 & 64.9 & $\ldots$ \\
Case Study: Peru & & & & \\
Total NPL ratio & 1.6 & 79.3 & 14.9 & 33.0 \\
$\quad$ Foreign currency NPL ratio & 1.4 & 79.3 & 14.9 & 33.0 \\
Total provisioning ratio & 2.0 & 79.3 & 14.9 & 30.0 \\
Foreign currency provisioning ra & 1.9 & 79.3 & 14.9 & 33.0 \\
\hline
\end{tabular}

Note: Fund staff estimates.

1/ Estimates in the case of Brazil, Chile, and Slovakia were not statistically different from zero.

The parameter estimates can be added to the set of early warning tools of risk management and bank supervision. Figure 1 shows the results of stress testing credit risk exposures to various size exchange rate shocks for Peru. The parameter estimate for foreign currency provisions in Table 3 together with information on profits, capital, and risk-weighted assets (information available to risk mangers as well as to supervisors) can be combined to assess the effect of a given exchange rate shock on the capital adequacy ratio. According to our estimates, a 30 percent devaluation will reduce the CAR from 14 to 12 percent. $^{32}$ Furthermore, a 70 percent devaluation will push the CAR below the minimum regulatory level (9.21 percent). A similar analysis can also be used to determine the minimum CAR level necessary to withstand a given devaluation. For example, according to our estimates, the minimum CAR level to withstand a 20 percent exchange rate shock would be 10.6 percent.

\footnotetext{
${ }^{32}$ Simulations assume that additional provision requirements due to depreciation cannot be met with profits, only with existing capital.
} 
Figure 3. Peru: Effect of Currency-Induced Credit Risk on the Solvency of the Banking System

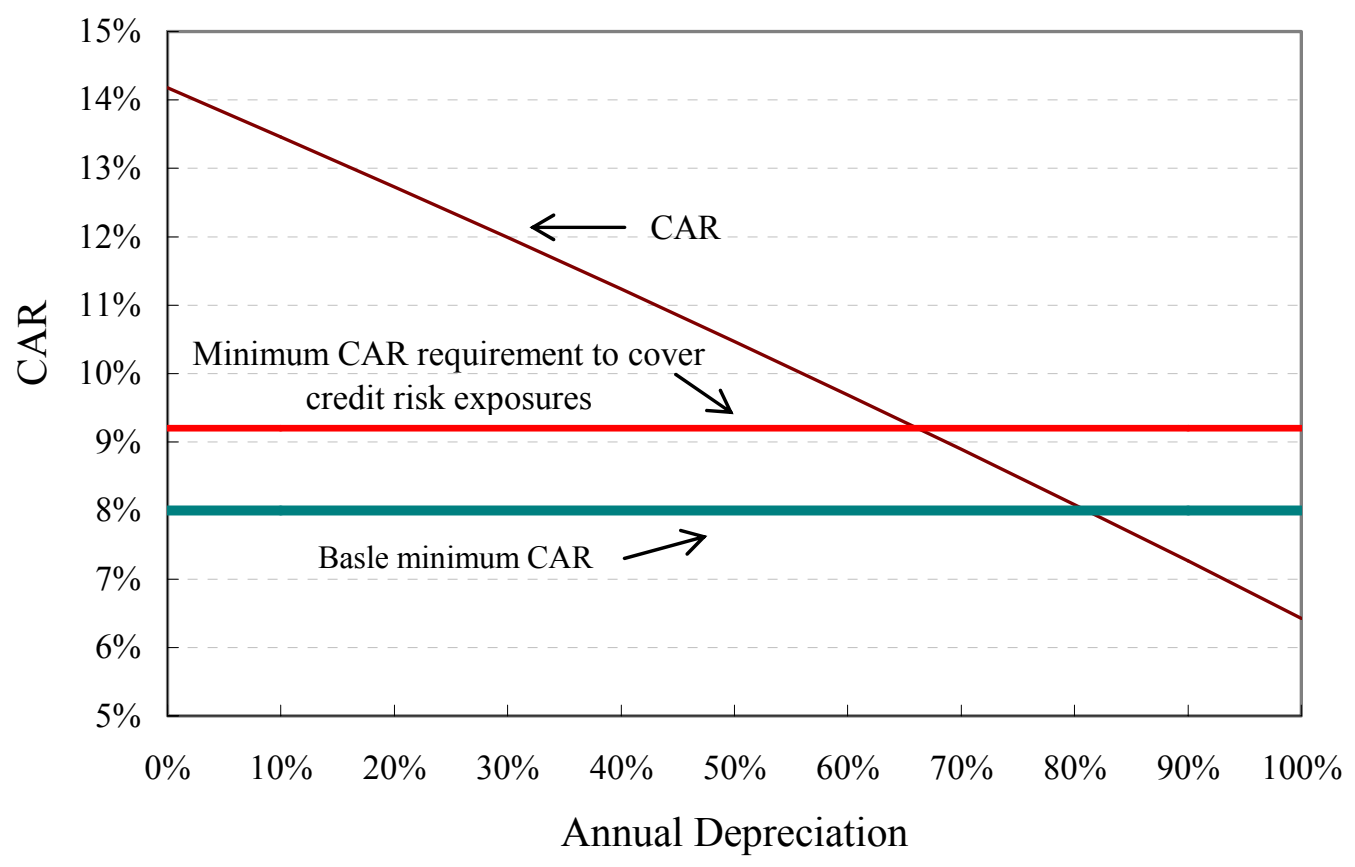




\section{References}

Abrams, R., and P. Beato, "The Prudential Regulation and Management of Foreign Exchange Risk," IMF Working Paper 98/37 (Washington: International Monetary Fund).

Basel Committee on Banking Supervision, 1980, "Supervision of Banks' Foreign Exchange Positions," (August) (Basel: Bank for International Settlements).

, 1988, "International Convergence of Capital Measurement and Capital Standards," (July) (Basel: Bank for International Settlements).

, 1997, "Core Principles for Effective Banking Supervision,” (April) (Basel: Bank for International Settlements).

,1998, "Amendment to the Capital Accord to incorporate Market Risks," (January 1996, updated to 1998) (Basel: Bank for International Settlements).

-, 1999, "Principles for the Management of Credit Risk," (July) (Basel: Bank for International Settlements).

, 2000, "Sound Practices for Managing Liquidity in Banking Organizations," (February) (Basel: Bank for International Settlements).

_ , 2003, “The New Basel Capital Accord,” (April) (Basel: Bank for International Settlements).

, 2004, "Implementation of Basel II: Practical Considerations," (July) (Basel: Bank for International Settlements).

_ 2005, "International Convergence of Capital Measurement and Capital Standards: A Revised Framework," (Basel: Bank for International Settlements).

Calvo, G., and C. Reinhart, 2002 "Fear of Floating," Quarterly Journal of Economics, Vol. 117, No. 2, pp. 379-408.

Cortavarria, L., C. Dziobeck, A. Kanaya, and I. Song, "Loan Review, Provisioning and Macroeconomic Linkages," IMF Working Paper 00/195 (Washington: International Monetary Fund).

de Nicolo, G., P. Honohan, and A. Ize, 2003, "Dollarization of the Banking System: Good or Bad?," World Bank Policy Research Working Paper No. 3116. 
Escobar, F., 2004, "Efectos de las variaciones del tipo de cambio sobre las actividades de intermediación financiera del sistema financiero boliviano 1990-2003," Documento de Trabajo del Banco Central de Bolivia (La Paz: Banco Central de Bolivia).

Goldman Sachs Global Equity Research, 2000, “Asian Banks NPLs, III,” (December) (New York).

Goldstein, M., and P. Turner, 2004, "Controlling Mismatches in Emerging Markets" (Washington: Institute for International Economics).

Gulde, A.M., D. Hoelscher, A. Ize, D. Marston, and G De Nicolo, 2004, "Financial Stability in Dollarized Economies," IMF Occasional Paper 230 (Washington: International Monetary Fund).

Financial Stability Institute, 2004, "Implementation of the New Capital Adequacy Framework in Non-Basel Committee Member Countries," Occasional Paper No 4. (Basel: Bank for International Settlements).

Heytens, P., and C. Karacadag, 2001, “An Attempt to Profile the Finances of China's Enterprise Sector,” IMF Working Paper 01/182 (Washington: International Monetary Fund).

Ize, A., and A. Powell, 2004, "Prudential Responses to de Facto Dollarization," IMF Working Paper 04/66 (Washington: International Monetary Fund).

Ize, A., M. Kiguel, and E. Levy Yeyati, 2005, "Managing Systemic Liquidity Risk in a Financially Dollarized Economy,” IMF Working Paper 05/188 (Washington: International Monetary Fund).

Reinhart, C., K. Rogoff, and M. Savastano, 2003, “Addicted to Dollars” NBER Working Paper 10015 (Cambridge, Massachusetts: National Bureau of Economic Research).

Tornell, A., and F. Westermann, 2005, Boom-Bust Cycles and Financial Liberalization, MIT Press. 